\title{
NILAI PENTING DAN STRATEGIS NASIONAL RENCANA ZONASI KAWASAN TAMAN NASIONAL KOMODO \author{
of the Komodo National Park
} \\ National Strategic and Important Value For Zoning Plan
}

\author{
*Suraji', Syofyan Hasan', Suharyanto', Yonvitner², Sonny Koeshendrajana ${ }^{3}$, \\ Didit Eko Prasetiyo', Arief Widianto', dan Agus Dermawan ${ }^{4}$ \\ ${ }^{1}$ Direktorat Perencanaan Ruang Laut, Ditjen Pengelolaan Ruang Laut, Kementerian Kelautan dan Perikanan, \\ JI. Medan Merdeka Timur No. 16 GMB III Lantai 9. Jakarta, Indonesia \\ ${ }^{2}$ IPB University \\ JI. Raya Dramaga Kampus, IPB Dramaga Bogor, 16680 Jawa Barat, Indonesia \\ ${ }^{3}$ Balai Besar Riset Sosial Ekonomi Kelautan dan Perikanan, \\ Jalan Pasir Putih Nomor 1 Ancol Timur, Jakarta Utara, Indonesia \\ ${ }^{4}$ Sekretariat Direktorat Jenderal Pengelolaan Ruang Laut, Kementerian Kelautan dan Perikanan, \\ JI. Medan Merdeka Timur No. 16 GMB III Lantai 11. Jakarta, Indonesia \\ Diterima tanggal: 12 April 2020; Diterima setelah perbaikan: 3 Juni 2020; \\ Disetujui terbit: 30 Juni 2020
}

\begin{abstract}
ABSTRAK
Kawasan Taman Nasional Komodo dan sekitarnya merupakan salah satu kawasan strategis nasional. Penetapan kawasan ini dikarenakan kawasan Taman Nasional Komodo dan sekitarnya yang terletak di Pulau Flores dan Pulau Sumbawa memiliki potensi dan nilai penting strategis untuk dikembangkan sebagai penggerak ekonomi nasional berbasis perlindungan keanekaragaman hayati. Penelitian bertujuan untuk mengkaji nilai penting dan strategis nasional rencana zonasi kawasan strategis Taman Nasional Komodo. Data primer dan sekunder digunakan dalam penelitian ini. Metode penentuan nilai penting dan strategis nasional yang diwujudkan dalam struktur dan pola ruang Rencana Zonasi Kawasan Strategis Nasional (RZ KSN) menggunakan teknik analisis multikriteria yang terdiri dari kebijakan yang bersifat mutlak, scoring/pembobotan dan kesepakatan para pihak. Hasil analisis pola ruang laut bernilai penting dan strategis nasional, terdiri dari: Kawasan Pemanfaatan Umum (Pariwisata, Pelabuhan, Pelabuhan Perikanan, Pengelolaan Energi) dan Kawasan Konservasi yang berupa Kawasan Konservasi Perairan, Pesisir dan Pulau-pulau Kecil dan Taman Nasional Komodo yang merupakan inti dari KSN Taman Nasional Komodo serta Alur Laut. Analisis Nilai Penting dan Strategis Nasional yang telah dilakukan menghasilkan Perencanaan Ruang Laut yang bertujuan untuk: (i) mewujudkan kawasan yang dikembangkan untuk perlindungan dan pelestarian Taman Nasional Komodo dan konservasi perairan; dan (ii) kawasan yang berdaya saing berbasis pengelolaan Sumber Daya Kelautan dan pariwisata dengan prinsip berkelanjutan untuk kesejahteraan masyarakat. Hasil Kajian direkomendasikan menjadi bahan utama dalam penyusunan Rancangan Peraturan Presiden dan pengaturannya dapat dilaksanakan dalam satu ketetapan berupa Peraturan Presiden tentang Rencana Tata Ruang dan Rencana Zonasi Kawasan Strategis Nasional Taman Nasional Komodo.
\end{abstract}

Kata Kunci: nilai penting; strategis nasional, kawasan, taman nasional, komodo

\begin{abstract}
The Komodo National Park area and its surroundings are some of the national strategic areas. The designation of this area is due to its location on Flores Island and Sumbawa Island which have potential and importance value to encourage national economy based on biodiversity protection. The research aimed to examine the national strategic and important value of the zoning plan of the Komodo National Park strategic area. Primary and secondary data were used in this study. The method to determine national strategic and important value is embodied in the spatial structure and pattern of the National Strategic Area Zoning Plan (RZ KSN). It used a multi criteria analysis technique consisting of absolute policies, scoring/weighting, and agreement of the parties. The results of the analysis of marine space pattern for national strategic and important value consisted of public areas (tourism, ports, fisheries ports, and energy management) and conservation areas including marine conservation areas for coastal and small Islands, and Komodo National Park which are the core of the National Strategic Area, and the Sea Lanes. The analysis of national important and strategic values suggested marine spatial planning that
\end{abstract}


aims to: (i) develop protection and conservation of the Komodo National Park and marine conservation areas; and (ii) establish competitive region based on management of sustainable marine resources and tourism for the welfare of the community. The results of the Study are recommended to be the main ideas in the drafting of the presidential regulation and its arrangements can be carried out in one stipulation in the form of a Presidential Regulation on Spatial Planning and Zoning Plans for the Strategic National Area of Komodo National Park.

Keywords: important value; national strategic; area; national park; komodo

\section{PENDAHULUAN}

Kawasan Taman Nasional Komodo dan sekitarnya merupakan salah satu kawasan strategis nasional (KSN) yang tercantum dalam Peraturan Pemerintah No 13 tahun 2017 tentang Rencana Tata Ruang Wilayah Nasional. Penetapan kawasan ini dikarenakan karena kawasan Taman Nasional Komodo dan sekitarnya yang terletak di Pulau Flores dan Pulau Sumbawa memiliki potensi dan nilai penting strategis untuk dikembangkan sebagai penggerak ekonomi nasional dan perlindungan keanekaragaman hayati. Pengembangan kawasan yang merupakan aglomarasi kekayaan alam dan sosial budaya yang berada di Kabupaten Manggarai Barat dan Kabupaten Bima ini diharapkan dapat memberikan sejumlah informasi dasar yang berguna untuk proses penataan dan pengelolaan kawasan pantai dan pesisir sebagai bagian dari Pengelolaan Kawasan Pesisir Secara Terpadu (Integrated Coastal Zone Management//ICZM).

Taman Nasional Komodo merupakan satu dari tujuh keajaiban dunia yang memiliki daya tarik tersendiri dengan adanya hewan reptil raksasa Komodo (Varanus komodoensis) serta keindahan bentang alam pulau-pulau kecil dan keanekaragaman hayati bawah laut menjadikan kawasan ini sebagai magnet pariwisata dunia. Peningkatan kunjungan wisatawan dapat menjadi salah satu ancaman terhadap kelestarian dan keanekaragaman sumber daya kawasan Taman Nasional komodo, sehingga perlu dilakukan penataan alokasi ruang lautuntukmelindungisumber daya dan lingkungan laut, serta memanfaatkan potensi sumber daya perairan di KSN Kawasan Taman Nasional Komodo.

Sesuai dengan amanat Undang-Undang Republik Indonesia Nomor 32 Tahun 2014 tentang Kelautan Pasal 42, serta arahan kebijakan maritim dan kelautan sebagaimana tercantum dalam RPJMN 2015-2019, maka perlu disusun Peraturan Presiden tentang Rencana Zonasi KSN Kawasan Taman Nasional Komodo yang diawali dengan kajian Identifikasi nilai penting dan strategis nasional. Metode baru yang dikembangkan Kementerian Kelautan dan Perikanan (Kementerian Pariwisata, 2018b) ini menjadi salah satu bagian penting dalam penyusunan dokumen rencana zonasi (RZ), yang diwujudkan dalam pola ruang laut rencana zonasi kawasan strategis nasional. Dokumen final RZ KSN merupakan materi teknis pokok dalam penyusunan Peraturan Presiden tersebut.

Tujuan penelitian ini adalah untuk: (1) Mengidentifikasi isu strategis dan kondisi potensi sumber daya perairan Kawasan Strategis Nasional Kawasan Taman Nasional Komodo; (2) Menentukan nilai penting dan strategis nasional sebagai landasan penetapan alokasi ruang laut; dan (3) formulasi tujuan, kebijakan dan strategi dalam Rencana Zonasi Kawasan Strategis Nasional Kawasan Taman

\section{METODOLOGI}

Penelitian ini merupakan penelitian kualitatif-sosial deskriptif yang menyajikan sebagian tahapan dalam penyusunan rencana zonasi kawasan strategis nasional kawasan Taman Nasional Komodo.

\section{Lokasi dan Waktu Penelitian}

Penelitian dilaksanakan di kawasan strategis nasional (KSN) Kawasan Taman Nasional Komodo yang mencakup wilayah Kabupaten Manggarai Barat, Provinsi Nusa Tenggara Timur sampai dengan Kabupaten Bima, Provinsi Nusa Tenggara Barat. Wilayah perencanaan seluas $971.768 \mathrm{Ha}$, yang meliputi sebagian perairan Laut Sawu dan Laut Flores. Waktu penelitian dilaksanakan selama 8 (delapan) Bulan, dimulai pada Bulan Mei 2018 sampai dengan bulan Desember 2018.

Batas wilayah perencanaan RZKSNKawasan TN Komodo adalah dari batas wilayah administrasi kecamatan pesisir sampai batas 12 mil ke arah laut yang diukur dari garis pantai, dengan batas-batas yang mencakup bagian wilayah sebagai berikut: 
(1) Sebelah utara: 12 mil dari garis pantai Kecamatan Macang Pacar, Kecamatan Komodo. (2) Sebelah timur: Perairan Laut Flores. (3) Sebelah selatan: Perairan Selat Sumba, dan (4) Sebelah barat: Pesisir di Kecamatan Sape dan Kecamatan Lambu (Kementerian Kelautan dan Perikanan, 2018a). Deliniasi batas wilayah perencanaan disajikan dalam Peta Lokasi Penelitian (Wilayah Perencanaan RZ KSN Komodo) sebagaimana Gambar 1.

\section{Jenis dan Metode Pengambilan Data}

Jenis Data Berupa Data Sekunder dan Data Primer. Jenis dan Metode pengambilan data, terdiri dari:

a. Studi dokumen perencanaan ruang, dilakukan sebagai langkah awal atau referensi untuk pelaksanaan kegiatan dalam rangka sinkronisasi tata ruang. Diantaranya referensi terkait: Rencana Zonasi wilayah Pesisir dan Pulau-Pulau Kecil (RZWP-3-K) Provinsi Nusa Tenggara Barat (Perda No.12 Tahun 2017); Rencana Zonasi wilayah Pesisir dan Pulau-Pulau Kecil (RZWP-3-K) Provinsi Nusa Tenggara Timur (Perda No.4 Tahun 2017); Dokumen Rencana Tata Ruang Kawasan Strategis Nasional (RTR KSN) Kawasan Taman Nasional Komodo; Dokumen Rencana Tata Ruang Wilayah Kabupaten Manggarai Barat. b. Data sekunder yang meliputi: (1). peta dasar, yang berupa: garis pantai; bathimetri; dan batas wilayah Laut. (2). data tematik, yang berupa: sistem jaringan prasarana Laut atau utilitas Laut; bangunan dan instalasi di Laut; oseanografi; ekosistem pesisir dan pulau-pulau kecil; wilayah pertahanan Laut; sumber daya ikan; dan pemanfaatan ruang Laut yang telah ada dan rencana pemanfaatan. Pengumpulan data sekunder diperoleh dari instansi terkait, seperti instansi pemerintah, dunia usaha, akademisi, dan perwakilan masyarakat.

c. Data primer (Groundcheck Lapangan), meliputi: (1) Observasi dan pengumpulan data isu-isu yang bernilai penting dan strategis nasional; (2) Pengumpulan data pemanfaatan perairan laut (eksisting) dan infrastruktur. Hasil analisis citra satelit digunakan untuk groundcheck guna mengetahuijenis pemanfaatan wilayah lautyang ada di Kawasan TN Komodo; (3) Pengumpulan data struktur jaringan; (4) Groundcheck lokasi yang bernilai penting dan strategis nasional, untuk mengetahui lokasi dan sebarannya dilakukan groundcheck dengan menggunakan GPS, serta: (5) Pengumpulan data soial ekonomi dan perikanan, yang meliputi: a) demografi, meliputi: jumlah penduduk, gender, tenaga kerja, jumlah nelayan dan pembudidaya ikan, mata pencaharian, pendidikan; b) sosial, meliputi: wilayah masyarakat hukum adat (lokasi, batas dan karakteristik), wilayah penangkapan ikan secara tradisional (lokasi,

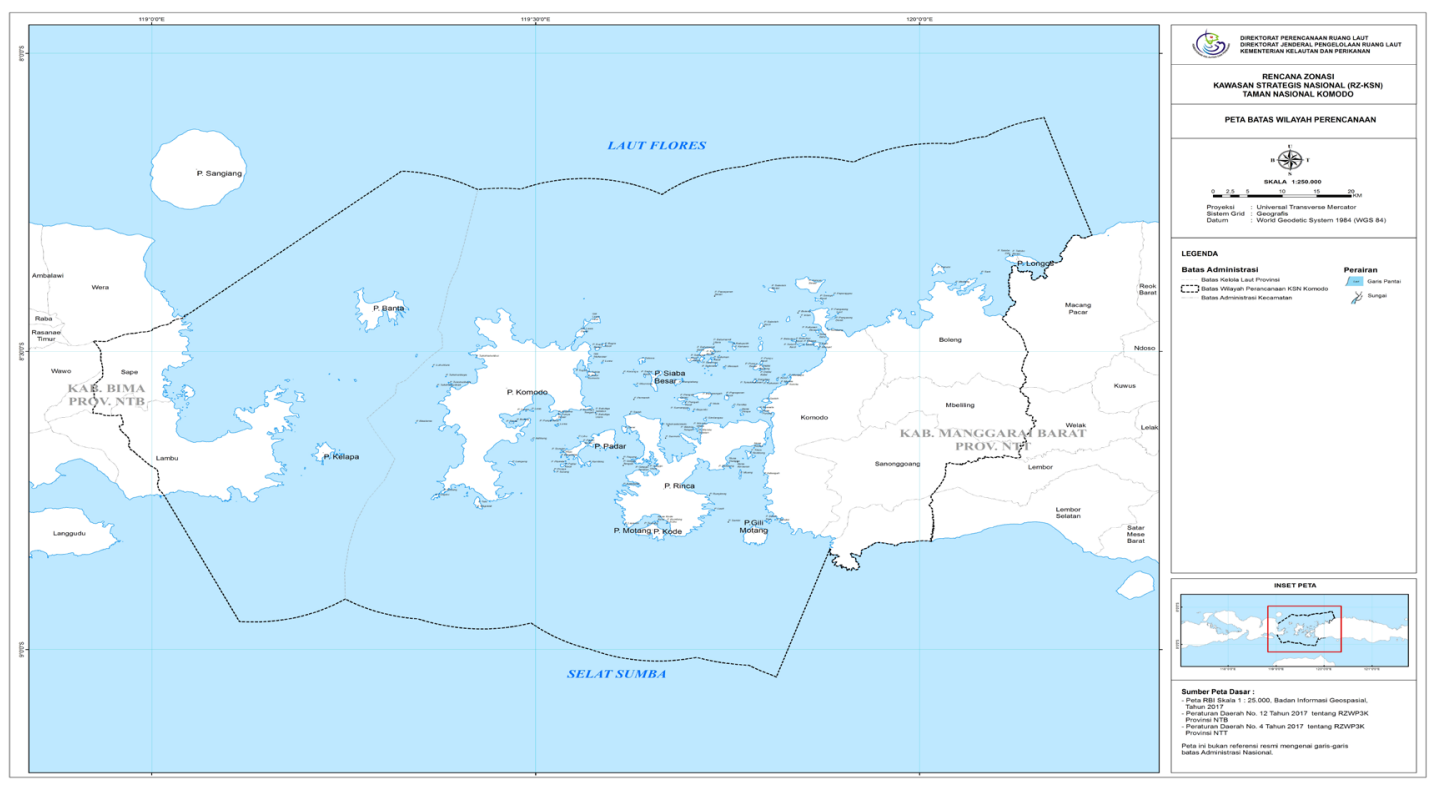

Gambar 1. Peta Lokasi Penelitian (Wilayah Perencanaan RZ KSN Komodo). Figure 1. Map of Research Location (Planning Area of RZ KSN Komodo). 
batas, dan karakteristik), kelembagaan; c) budaya, meliputi: kondisi dan karakteristik masyarakat setempat termasuk agama, tempat suci dan kegiatan peribadatannya, aktifitas/ ritual keagamaan, kearifan lokal, dan situs cagar budaya, dan; d) ekonomis, meliputi: pendapatan perkapita, pola pergerakan ekonomi wilayah, angkatan kerja dan tingkat pengangguran tenaga kerja, pendapatan di sektor perikanan, produksi perikanan, pendapatan rata-rata dan pengeluaran, serta komoditas unggulan.

Pengambilan dan pengumpulan data dilakukan dengan cara wawancara terstruktur maupun wawancara mendalam, observasi (pengamatan langsung) dan diskusi dengan kelompok-kelompok masyarakat (Focus Group Discussion).

\section{Metode Analisis}

Data sekunder dan data primer hasil groundcheck kemudian diolah untuk dituangkan dalam bentuk peta-peta tematik, tabular atau numerik. Analisis data dilakukan secara deskriptif kualitatif menggunakan teknik analisis multikriteria yang terdiri dari kebijakan yang bersifat mutlak, scoring/pembobotan dan kesepakatan para pihak. Tahapan analisis yang dilakukan, meliputi:

\section{1). Analisis spasial dan non spasial}

Analisis spasial dan non spasial dilakukan terhadap keseluruhan wilayah perencanaan RZ KSN untuk menentukan scenario kawasan/zona dan kompatibilitas antar kawasan/zona.

Analisis Spasial (analisis kesesuaian perairan) meliputi kegiatan sebagai berikut:

- Mendeliniasi masing-masing parameter petapeta tematik berdasarkan kriteria kesesuaian zona tertentu

- Melakukan tumpeng susun/overlay untuk menghasilkan peta-peta kesesuaian terhadap masing-masing zona

- Masing-masing peta-peta kesesuaian zona tersebut selanjutnya ditumpang susun/ overlay sehingga menghasilkan peta multi kesesuaian

Analisis non spasial, meliputi analisis terhadap kebijakan (RPJMN, RTRL, RTRWN, Rencana Induk Sektoral, dan kebijakan lainnya), analisis sosial budaya, analisis ekonomi wilayah, analisis pengembangan wilayah, serta analisis isu dan permasalahan.
2). Penentuan rencana alokasi ruang pada zona strategis nasional (analisis nilai penting dan strategis nasional)

Analisis dilakukan melalui 2 (dua) tahapan, yaitu:

a. Identifikasi dan analisis kepentingan nasional yang bersifat mutlak

Metode ini dilakukan dengan cara mengidentifikasi kegiatan bernilai penting dan strategis nasional yang telah memiliki ketetapan atau bersifat mutlak dilaksanakan pada kawasan tertentu dan merupakan kebijakan strategis nasional, seperti proyek strategis nasional, kepentingan pertahanan dan keamanan, minyak dan gas, pelabuhan, rencana tata ruang laut nasional, rencana tata ruang wilayah nasional, rencana pembangunan jangka menengah nasional, kawasan ekonomi khusus, kawasan strategis pengembangan pariwisata nasional, dan kebijakan yang bersifat ketetapan nasional lainnya. Astuti, Budisusanto, Pratomo dan Sidqi (2018) menempatkan kesesuaian peraturan perundangundangan pada tahapan penarikan kesimpulan dan rekomendasi pemanfaatan ruang laut, apakah sesuai atau tidak sesuai dengan rencana zonasi dan Undang-Undang yang berlaku.

\section{b. Analisis skoring}

Penentuan/Skoring Nilai Penting dan Strategis Nasional berdasarkan metode yang dikembangkan Kementerian Kelautan dan Perikanan (2018) sebagaimana matrik skoring nilai penting dan strategis nasional yang disajikan pada Tabel 1.

Pemberian nilai/skor (scoring) pada alokasi ruang laut yang sesuai dengan setiap kriteria dari kedua sudut pandang kawasan bernilai strategis penting adalah 0 (tidak sesuai) dan 1 (sesuai). Atas dasar nilai/skor yang diberikan untuk setiap kriteria, selanjutnya dilakukan penjumlahan nilai/ skor total untuk seluruh kriteria dari kedua sudut pandang kawasan sebagaimana diringkaskan dalam matriks, dengan kelas bobot nilai strategis nasional.

\section{3). Tahapan analisis keserasian peruntukan ruang pada Kawasan Strategis Nasional}

Analisis ini dilakukan untuk penentuan arahan alokasi ruang diluar zona strategis nasional, yaitu dilakukan dengan analisis keserasian antara rencana alokasi ruang di zona strategis nasional dan 
Tabel 1. Skoring Nilai Penting dan Strategis Nasional.

Table 1. Scoring of Important National Strategic Values.

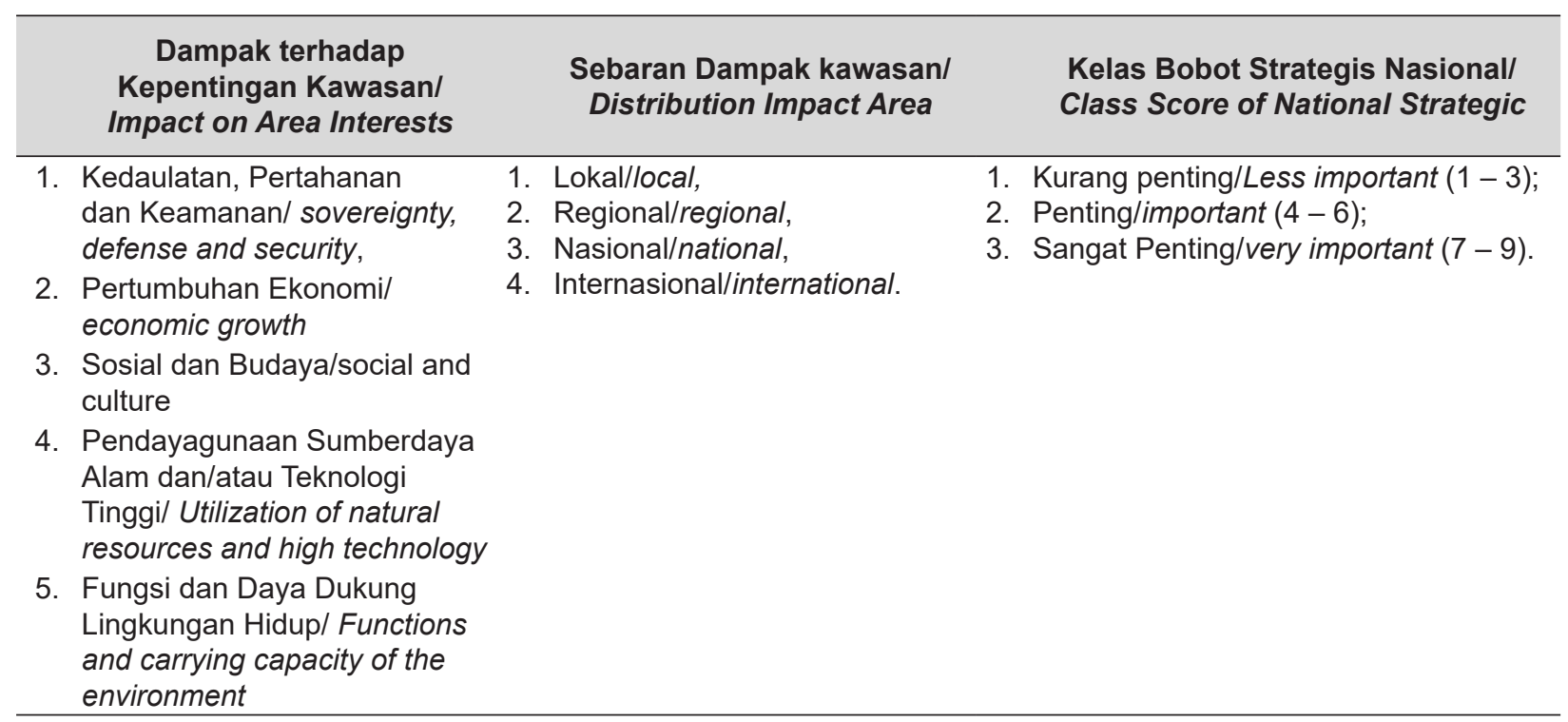

arahan alokasi ruang diluar zona strategis nasional (RZWP-3-K). Analisis dilakukan berdasarkan matriks kompatibilitas antar zona. Analisis ini dilakukan untuk mewujudkan keterpaduan, keserasian, keselarasan, dan keseimbangan, serta untuk memastikan agar pengaturan ruang di dalam wilayah perencanaan mendukung fungsi KSN.

\section{4). Proses penyepakatan alokasi ruang}

Proses ini dilakukan dengan tujuan untuk menyelesaikan konflik pemanfaatan ruang, mencapai kesepakatan terhadap draft RZ KSN, diantaranya terhadap rencana alokasi ruang pada zona strategis nasional dan arahan alokasi ruang di luar zona strategis nasional. Penyepakatan alokasi ruang ini melibatkan para pemangku kepentingan, yaitu: Instansi pemerintah, LSM, akademisi, swasta, kelompok masyarakat dan kelompok pemangku kepetingan yang terkait lainnya. Kegiatan ini dilakukan ditingkat pusat dan daerah/tapak. Metode pembahasan dilakukan melalui konsultasi publik dan diskusi kelompok terpumpun (Focus Group Discussion/FGD)

\section{HASIL DAN PEMBAHASAN}

Rencana Zonasi Kawasan Strategis Nasional (RZ KSN) TN Komodo mencakup wilayah perairan yang merupakan satu kesatuan ekosistem dengan wilayah daratan yang diatur dalam Rencana Tata Ruang (RTR) KSN Kawasan TN Komodo.

\section{Identifikasi Isu Strategis}

Isu-isu strategis yang berkembang berdasarkan hasil konsultasi publik pada umumnya terkait dengan pemanfaatan potensi sumber daya. Selanjutnya berdasarkan hasil identifikasi dan analisis. Isu-isu Strategis dikelompokkan dalam 3 (tiga) kelompok isu, antara lain: (1) isu daya dukung lingkungan hidup; (2) isu sosial dan ekonomi, dan; (3) isu regulasi dan kebijakan.

(1) Isu daya dukung lingkungan hidup. Penetapan TN Komodo dan Labuhan Bajo sebagai salah satu kawasan strategis pariwisata nasional berdasarkan Peraturan Pemerintah Nomor 50 Tahun 2011 dengan target 500.000 wisatawan/ tahun berpotensi mengakibatkan degradasi lingkungan dan melebihi daya dukung wisata di Kawasan TN Komodo (Yuneni, 2017). Degradasi lingkungan juga terjadi akibat pencemaran perairan yang disebabkan oleh aktivitas di wilayah hulu, limbah industri (asap pabrik, logam berat), limbah pertanian (penggunaan macam pupuk TSP, Urea, sianida), limbah sampah organik/anorganik yang dibuang diperairan dari kapal penumpang, kargo serta limbah rumah tangga seperti sampah plastik, kaleng bekas, deterjen dan limbah sisa makanan dari hotel). Isu lainnya, terkait penangkapan tidak ramah setasea (alat tangkap yang tidak sesuai walaupun diijinkan seperti jaring insang dan rawai (The Nature Conservancy Indonesia Coastal \& Marine Program, 2001), penangkapan yang merusak seperti bom, potassium dan Tuba, 
IUU Fishing), penangkapan yang tidak sesuai dengan perijinan (alat, armada dan lokasi). EAFM Indikator untuk kesesuaian fungsi dan ukuran kapal penangkapan ikan dengan dokumen legal dan indikator sertifikasi awak kapal perikanan sesuai dengan peraturan, pada tingkat kabupaten hampir tidak didapatkan informasi dan data karena mayoritas kapal yang digunakan nelayan di bawah 10 GT (Bessie \& Dewi, 2016). Daya dukung lingkungan hidup perlu mendapat perhatian, sebab TN Komodo memiliki keanekaragaman hayati yang tinggi. Di samping itu, wilayah perairan merupakan jalur migrasi biota laut (Kahn dalam The Nature Conservancy Indonesia Coastal \& Marine Program, 2001), serta adanya pencadangan kawasan konservasi perairan Pulau Banta dan Pulau Kelapa.

(2) Isu sosial dan ekonomi. Pembangunan dan investasi swasta di Kawasan TN Komodo, termasuk pengembangan wisata kapal wisata (Yacht) Asing (Kementerian Pariwisata, 2018b) dan rencana pengembangan di kawasan pesisir Labuhan Bajo merupakan isu utama dari aspek sosial-ekonomi. Isu sosial dan ekonomi lainnya, diantaranya aksesibilitas dan konektivitas kawasan Labuan Bajo, dengan adanya rencana pengembangan Bandar Udara. Strategi yang sesuai dengan posisi Bandar Udara Komodo Labuan Bajo adalah strategi agresif yang mendukung pertumbuhan bandar udara (Subekti \& Winahyu, 2015); rencana pemindahan lokasi pelabuhan umum dan pelabuhan perikanan di kawasan pesisir Labuhan Bajo (Kementerian Perhubungan, 2017; Kementerian Kelautan dan Perikanan, 2018c), dan kebutuhan penyediaan energi dan tenaga listrik (Kementerian ESDM, 2018). Adanya konflik antara masyarakat adat dengan pengelola Kawasan TN Komodo merupakan isu sosial yang perlu mendapat perhatian.

(3) Isu regulasi dan kebijakan. Kebijakan yang mengatur wilayah di lingkup TN Komodo saat ini belum mencakup perairan sekitar sebagai satu kesatuan ekosistem. Kebijakan yang mengatur wilayah di lingkup TN Komodo saat ini belum memuat alternatif pengalihan beban kawasan TN Komodo ke kawasan sekitar, maka perlu adanya strategi pengendalian yang mencakup kegiatan yang berkembang pesat dan menimbulkan ancaman degradasi lingkungan, dan strategi pengalihan yang berupa pengalihan sebagian beban kegiatan dari TN Komodo ke kawasan di sekitar TN Komodo yang memiliki potensi tinggi yang belum optimal. Strategi ini harus masuk ke dalam peraturan perundangan yang memayungi kegiatan pemanfaatan di wilayah tersebut, termasuk adanya Badan Otorita Pengelola Kawasan Pariwisata Labuan Bajo Flores (Peraturan Presiden republik Indonesia Nomor 32 Tahun 2018). Kebijakan yang mengatur wilayah di lingkup TN Komodo saat ini tidak memiliki instrumen hukum dalam memberikan izin yang menjadi kewenangan pusat di wilayah perairan TN Komodo sebagaimana amanat Undang-Undang No 32 Tahun 2014 tentang Kelautan. Isu regulasi dan kebijakan lainnya, diantaranya telah terdapat beberapa peraturan yang memuat kegiatan di wilayah TN Komodo dan sekitarnya, namun bersifat parsial dan sektoral, serta peraturan perundangan yang ditetapkan Kementerian/ Lembaga saat ini kurang mengikat secara komprehensif.

\section{Identifikasi Kondisi Potensi Sumber daya Perairan}

Kondisi dan potensi sumber daya alam kawasan strategis nasional kawasan Taman Nasional Komodo diidentifikasi dan dan dideskripsikan, antara lain:

\section{1). Keadaan oseanografi}

Perairan pesisir NTT secara umum memiliki batimetri/kedalaman yang bervariasi, dari yang dangkal sampai kedalaman lebih dari $300 \mathrm{~m}$ seperti peraian di selatan Lembata dan tenggara Alor. Perairan yang berada di hadapan daratan sampai 4 mil sebagian besar merupakan perairan dangkal dan semakin dalam pada jarak antara 4-12 mil, kecuali pada wilayah tertentu yang berdekatan dengan pulau-pulau lainnya. Perairan Selat Sape tergolong dangkal dan sangat landai, maksimum kedalaman di Teluk Sape adalah $70 \mathrm{~m}$. Perairan Teluk Labuhan Bajo, Teluk Slawi Pulau Komodo dan sekitarnya merupakan perairan dangkal dengan rentang kedalaman kurang dari $200 \mathrm{~m}$. Kecepatan arus dalam KSN TN Komodo diantaranya: Arus Barat - Pasang: 0,1 -0,2 meter/detik; Arus Barat Surut: 0,05 - 0,2 meter/detik; Arus Timur - Pasang: 0,05 - 0,25 meter/detik; dan Arus Timur - Surut: 0,05 - 0,55 meter/detik. Tinggi Gelombang Musim timur di sekitar Kawasan TN Komodo adalah 0,7 - 1,2 meter, sedangkan Tinggi Gelombang Musim barat adalah 0,7 - 1,6 meter. Adapun substrat dasar laut wilayah perairan KSN Taman Nasional Komodo terdiri dari 5 jenis sedimentasi dasar 
laut, yakni meliputi batu keras dan kerikil, koral, lempung, pasir dan lanau, serta selut gampingan. Adapun jenis yang mendominasi adalah lempung.

\section{2). Potensi Ekosistem Pesisir}

Keanekaragaman hayati terumbu karang di wilayah TN Komodo memiliki 385 jenis karang dan 40 dive site yang mempesona. Selain itu, di wilayah TN Komodo memiliki 23 jenis mangrove dan potensi ekosistem penting lainnya berupa padang lamun. Luas potensi ekosistem pesisir KSN TN Komodo sebagaimana disajikan pada Tabel 2.

\section{3). Potensi Daerah Penangkapan Ikan}

Tabel 2. Luas Potensi Ekosistem Pesisir KSN TN Komodo.

Table 2. Area of potential Ecosystem of KSN Komodo National Park.

\begin{tabular}{llc}
\hline No & Ekosistem/Ecosystem & $\begin{array}{c}\text { Luas Tutupan/ } \\
\text { Coverage Area (Ha) }\end{array}$ \\
\hline 1 & Mangrove/Mangrove & $2,096.20$ \\
2 & Lamun/Seagrass & $3,250.26$ \\
3 & Terumbu Karang/ & $5,029.54$ \\
& Coral Reef & \\
\hline
\end{tabular}

Sumber: KKP, 2018/Source: KKP, 2018

a. Daerah Penangkapan Ikan Pelagis. Potensi perikanan tangkap pelagis dalam kawasan TN Komodo paling tinggi berada di perairan utara, tingkat potensi penangkapan ikan pelagis sedang berada di selatan perairan Gili Motang, sedangkan tingkat potensi penangkapan ikan pelagis rendah berada disekitar perairan Teluk Sape.

b. Daerah Penangkapan Ikan Demersal. Potensi perikanan tangkap demersal dalam kawasan TN Komodo tersebar luas di perairan utara TN Komodo dan perairan disekitar Teluk Sape. Ikan demersal yang berada di sekitar kawasan TN Komodo diantaranya adalah gurita, lobster, cumi-cumi, dan kepiting.

\section{4). Potensi Daerah Tujuan Wisata Selam}

Daerah tujuan wisata laut paling banyak tersebar di dalam kawasan taman nasional komodo, dimana wisata yang banyak diminati adalah wisata selam, karena TN Komodo memiliki potensi alam bawah laut yang indah untuk dikunjungi wisatawan, selain itu beberapa spot wisata dalam TN Komodo merupakan titik temu beberapa biota dilindungi seperti pari manta, hiu, dan penyu. Hasil analisis potensi disajikan dalam peta daerah tujuan wisata laut (titik penyelaman) di wilayah perencanaan RZ KSN Komodo sebagaimana pada Gambar 2.

\section{5). Kawasan Konservasi dan Biota Dilindungi}

Kawasan konservasi yang berada didalam wilayah KSN kawasan TN Komodo diantaranya adalah: (a) Kawasan Konservasi Perairan Daerah Pulau Banta yang telah ditetapkan oleh SK Gubernur NTB No 523-505 tanggal 25 Mei 2016; (b) Pencadangan Kawasan Konservasi Perairan Daerah Pulau Kelapa yang telah dialokasikan dalam dokumen Perda RZ WP3K NTB; (c) Pencadangan Kawasan Konservasi Perairan Daerah Pulau

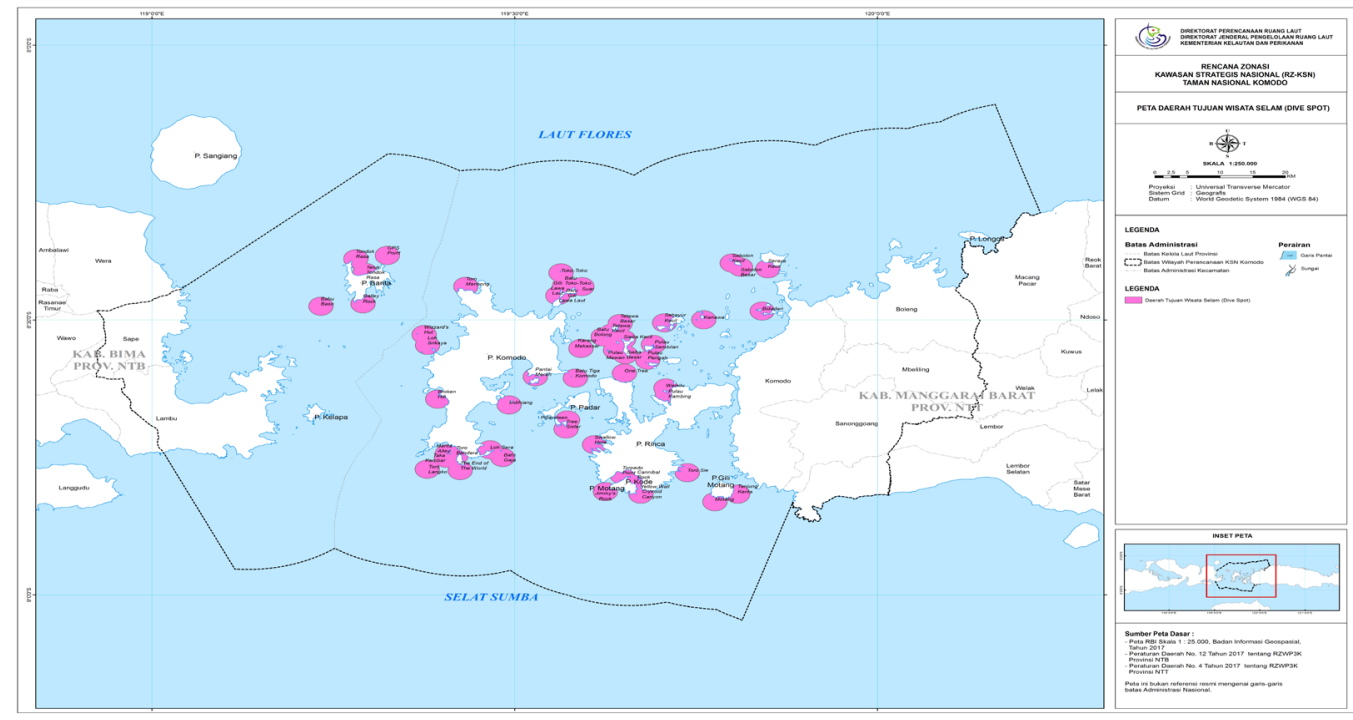

Gambar 2. Peta Tujuan Wisata (Titik Selam) di Wilayah Perencanaan RZ KSN Komodo.

Figure 2. Map of Tourism Destination (Dive Spot) in Planning Area of RZ KSN Komodo. 
Longos yang telah dialokasikan dalam dokumen Perda RZ WP3K NTT, dan (d) Taman Nasional Komodo yang telah ditetapkan oleh Keputusan Menteri Kehutanan dan Perkebunan Nomor 172/ KPTS-II/2000. Sedangkan jenis biota dilindungi yang tersebar didalam wilayah KSN kawasan TN Komodo diantaranya Pari Manta, Hiu, dan Penyu. Hasil overlay Peta kawasan konservasi di wilayah perencanaan RZ KSN Komodo sebagaimana disajikan pada Gambar 3.

\section{6). Daerah Rawan Tsunami}

Bencana alam merupakan fenomena alam yang memberikan dampak negatif bagi segenap kehidupan. Antisipasi dini terhadap bencana alam (mitigasi bencana) sangat diperlukan untuk memperkecil dampak negatif dari bencana tersebut. KSN Taman Nasional Komodo rawan terhadap bencana alam, terutama tsunami sebagaimana disajikan pada Gambar 4.
7). Kegiatan Pemanfaatan Perairan Pesisir

a. Pemanfaatan eksisting. Perairan pesisir dan seluruh sumber dayanya sejauh 12 mil yang dalam hal ini adalah perairan pesisir di Kawasan Strategis Nasional TN Komodo, selama ini telah dimanfaatkan oleh masyarakat, birokrat, dan pengusaha (investor). Pemanfaatan yang dilakukan oleh manusia untuk kepentingan konservasi (biologi, ekologi), ekonomi, sosialbudaya, teknologi, dan hukum.

b. Sunyowati (2008) menyatakan bahwa beragam karakteristik pemanfaatan ruang laut, membawa dampak munculnya isu dan permasalahan yang terkait penataan ruang jika tidak dikelola secara terkoordinasi dan terpadu. Berdasarkan skala waktu pemanfaatan, pemanfaatan perairan dapat dibedakan atas pemanfaatan menetap dan pemanfaatan tidak menetap. Pemanfaatan menetap yaitu pemanfaatan perairan yang telah memiliki ijin dan/atau penetapan atau

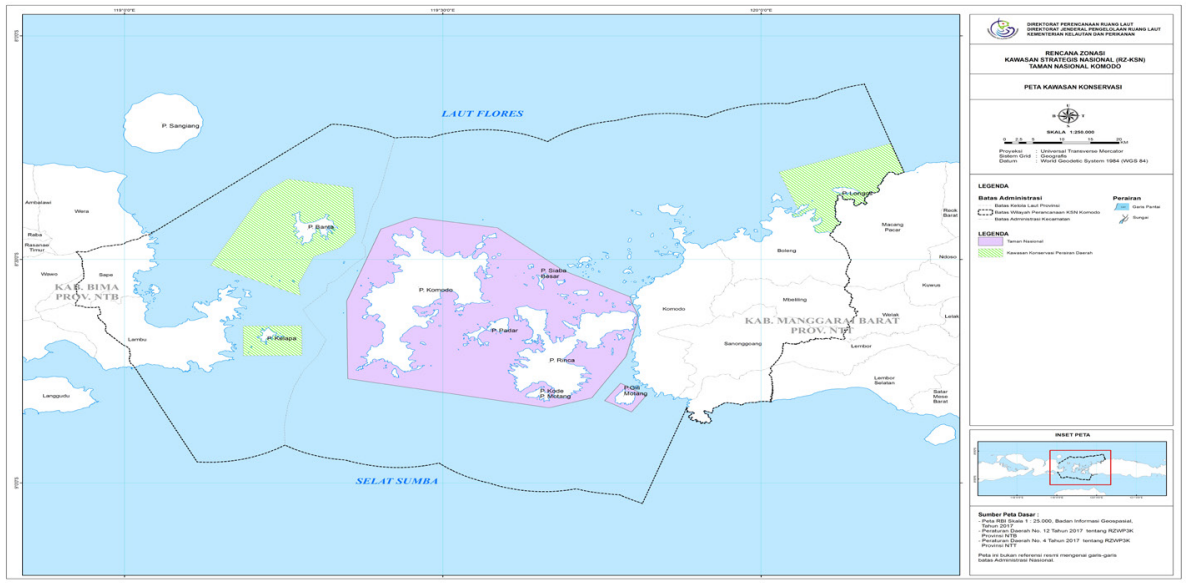

Gambar 3. Peta Kawasan Konservasi di Wilayah Perencanaan RZ KSN Komodo. Figure 3. Map of Conservation Area in Planning Area of RZ KSN Komodo.

Sumber: KKP (2018a)/Source: KKP (2018a)

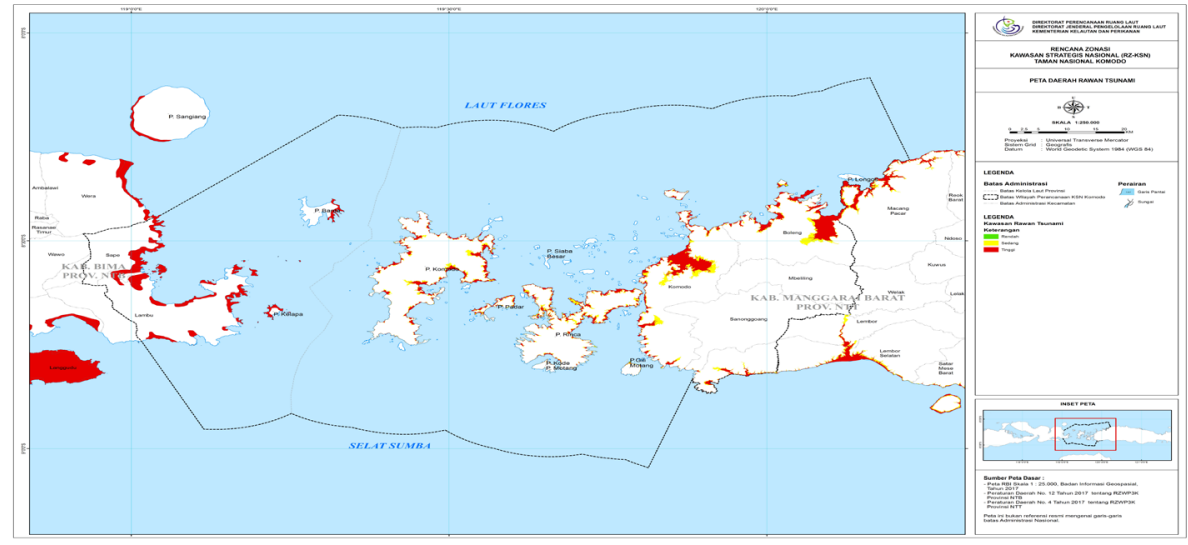

Gambar 4. Peta Resiko Bencana Tsunami di Wilayah Perencanaan RZ KSN Komodo. Figure 4. Map of Tsunami Disaster Risk in Planning Area of RZ KSN Komodo. 
tidak memiliki ijin yang berlangsung secara terus menerus pada suatu lokasi tertentu atau tidak berpindah-pindah. Pemanfaatan perairan menetap, antara lain kawasan konservasi, Daerah Lingkungan Kerja Pelabuhan dan Daerah Lingkungan Kepentingan Pelabuhan (DLKp/ DLKr), budidaya laut, bagan tancap, sarana navigasi pelayaran, dan sarana maritim lainnya. Sedangkan pemanfaatan tidak menetap yaitu pemanfaatan perairan tidak secara terus menerus di suatu lokasi, seperti penangkapan ikan dan wisata bahari. Hasil analisis tumpang susun terhadap kegiatan pemanfaatan perairan pesisir eksisting disajikan dalam peta pemanfaatan eksisting di wilayah perencanaan
RZ KSN Komodo sebagaimana Gambar 5.

c. Kawasan Konservasi (Taman Nasional Komodo). Surat Keputusan Menteri Kehutanan Nomor 172/Kpts-II/2000 tanggal 29 Juni 2000 dengan total luas $173.300 \mathrm{Ha}$ dimana luas wilayah perairan sebesar $114.801 \mathrm{Ha}$ dan wilayah daratan sebesar $58.499 \mathrm{Ha}$. Zonasi TN Komodo disahkan berdasarkan Surat Keputusan Direktur Jenderal Perlindungan Hutan dan Konservasi Alam Nomor SK.21/IV-SET/2012 tentang Zonasi Taman Nasional Komodo (Kementerian Kehutanan, 2012). Peta Rencana Zonasi TN Komodo sebagaimana disajikan pada Gambar 6.

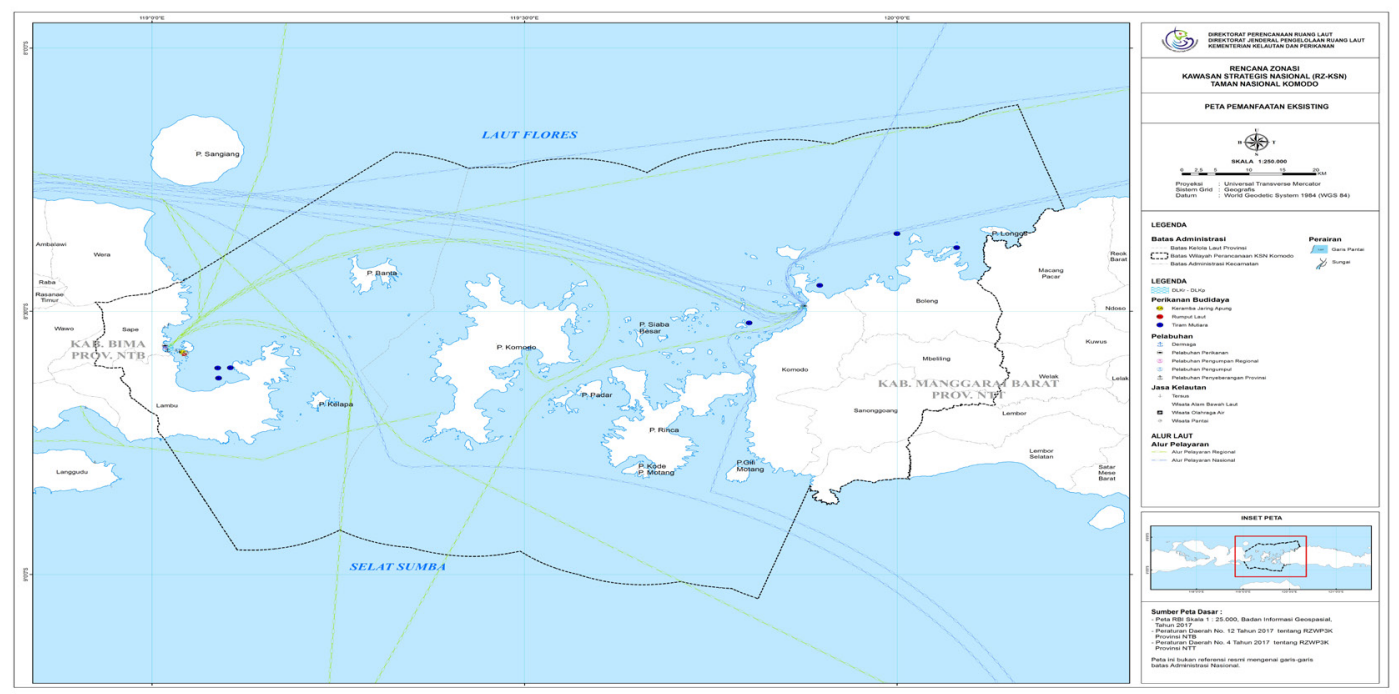

Gambar 5. Peta Pemanfaatan Eksisting di Wilayah Perencanaan RZ KSN Komodo. Figure 5. Map of Existing Utilization in Planning Area of RZ KSN Komodo. Sumber: KKP (2018a)/Source: KKP (2018a)

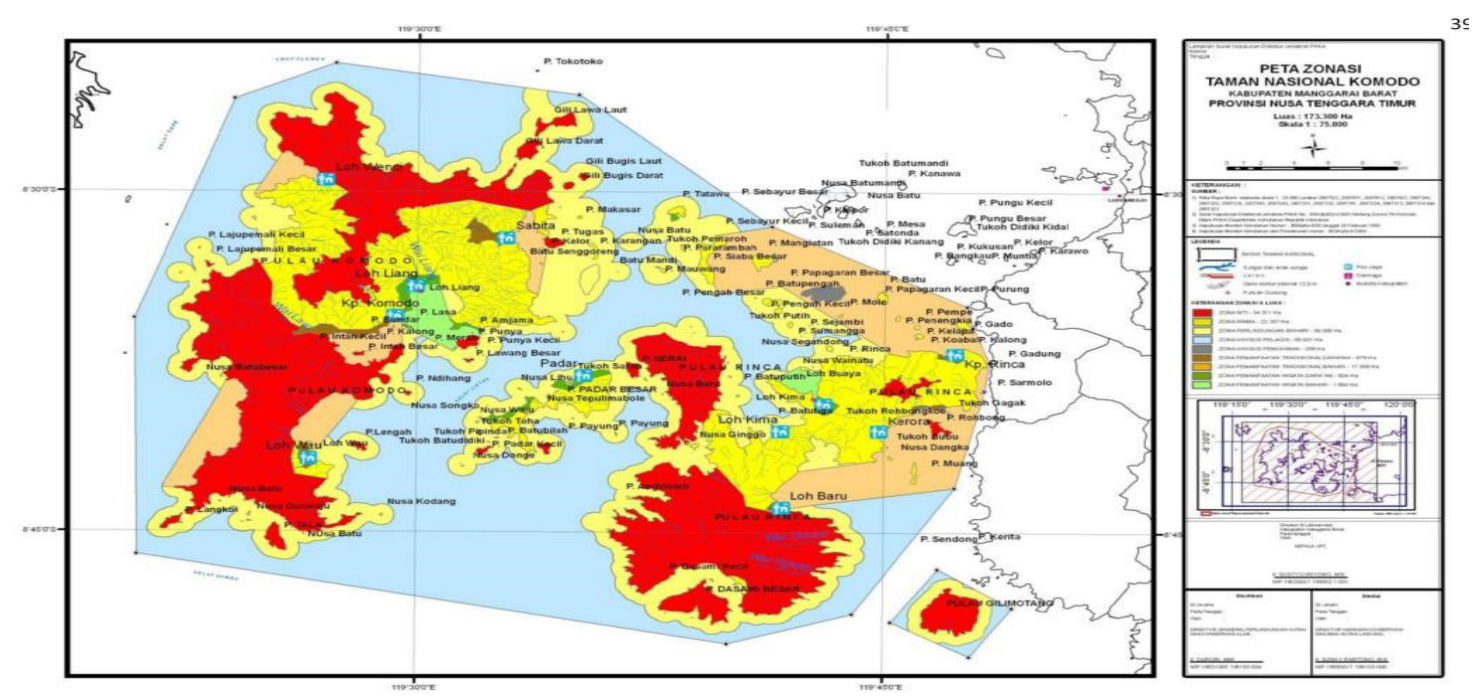

Gambar 6. Peta Rencana Zonasi TN Komodo. Figure 6. Map of Komodo National Park Zoning Plan.

Sumber: Kementerian Kehutanan (2012)/Source: Ministry of Forestry (2012) 
d. Perikanan Budidaya Laut. Kegiatan perikanan budidaya Provinsi NTT termasuk di Kabupaten Manggarai Barat, pada umumnya terdiri dari: rumput laut, mutiara, ikan hias dengan potensi investasi yang cukup besar. Adanya wilayah kelautan yang cukup luas merupakan modal utama untuk pengembangan budidaya perikanan laut, khususnya untuk jenis ikan hidup, diantaranya kerapu tercatat produksinya mencapai 3 ton pada tahun 2014 (Dinas Kelautan dan Perikanan Provinsi Nusa Tenggara Timur, 2015). Produksi rumput laut Kabupaten Manggarai Barat pada tahun 2014 sebesar 157,7 ton dan berdasarkan data c menunjukkan peningkatan produksi. Walaupun kontribusinya sangat kecil terhadap produksi rumput laut Provinsi NTT. Bupati Manggarai Barat telah mengeluarkan Peraturan Bupati Nomor 43 Tahun 2018 tentang Ketentuan Pemanfaatan Ruang dan ljin Prinsip Pemanfaatan Ruang Labuan Bajo. Produksi rumput laut per tahun Kabupaten Manggarai Barat dan Provinsi NTT disajikan pada Gambar 7.

e. Perikanan Tangkap. Perairan di Manggarai Barat, khususnya di Selat Molo dikenal memiliki arus laut yang kuat, yang disebabkan oleh perubahan arus harian antara kawasan lautan lepas (Lautan Hindia) dan laut pedalaman seperti di kawasan Kepulauan Komodo-Rinca dan Laut Flores.

Kecamatan Komodo merupakan kecamatan dengan produksi ikan tertinggi. Hal ini dikarenakan kecamatan ini memiliki luasan areal penangkapan yang paling besar diantara ketiga kecamatan lainnya. Selain disebabkan oleh luasan areal kecamatan, jumlah nelayan di kecamatan Komodo terbanyak di Kabupaten Manggarai Barat.

Praktek penangkapan ikan tidak ramah lingkungan masih dijumpai di wilayah ini. Upaya peningkatan intensitas patroli diperlukan untuk mengurangi praktek penangkapan ikan yang merusak, seperti penggunaan bahan peledak dan potassium serta peningkatan pemasangan mooring buoy secara permanen. (Sartin, Amkieltiela \& Khaifin, 2017). Selain itu, kerentanan sumber daya perikanan tangkap juga dapat disebabkan oleh alat tangkap yang digunakan. Menurut Penelitian Yonvitner, Boer, Akmal \& Andi (2018), alat tangkap yang berpotensi menyebabkan kerentanan menurut tropik level terbesar adalah Denish Seine dan Encircling gillnet. Sedangkan berdasarkan hasil tangkapan dari penelitiannya yang dilakukan di Banten, alat yang berpotensi menyebabkan kerusakan adalah gillnet dan pancing. Jumlah Nelayan di Kabupaten Manggarai Barat yang dirinci menurut jenis nelayan sebagaimana disajikan pada Tabel 3.

Jumlah nelayan penuh terbanyak di Kabupaten Manggarai Barat berturut-turut adalah Kecamatan Komodo, Boleng, Lembor Selatan dan Macang Pacar. Kondisi ini berbeda dengan jumlah nelayan sambilan utama terbanyak ada di Kecamatan Boleng, diikuti Kecamatan Komodo dan terkecil adalah Kecamatan Macang Pacar. Data sebaran nelayan dapat dijadikan sebagai bahan pertimbangan penetapan responden kaitannya dengan kajian peforma perikanan khususnya domain sosial dan ekonomi.

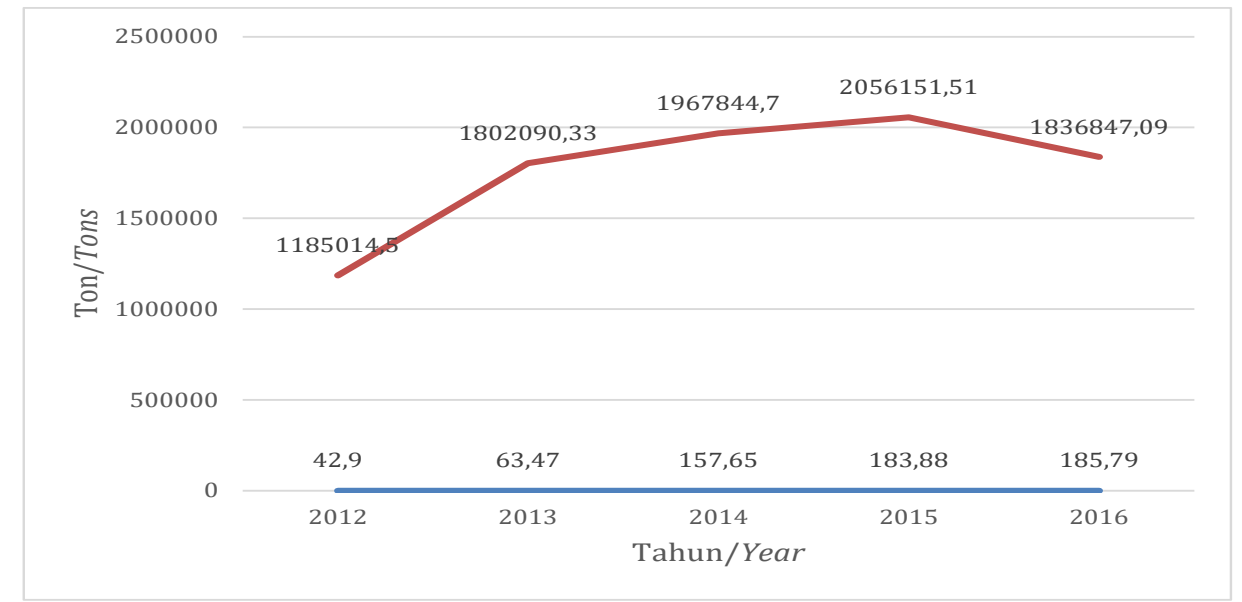

Gambar 7. Produksi Rumput Laut Kabupaten Manggarai Barat dan Provinsi NTT 2012-2016. Figure 7. Production of Seaweed in West Manggarai Regency and NTT Province 2012-2016. 
Tabel 3. Jumlah Nelayan di Kabupaten Manggarai Barat yang Dirinci Menurut Jenis Nelayan Tahun 2015.

Table 3. Number of Fishers in West Manggarai Regency Detailed by Type of Fishers in Year 2015.

\begin{tabular}{lcccc}
\hline $\begin{array}{c}\text { Kecamatan/ } \\
\text { District }\end{array}$ & $\begin{array}{c}\text { Nelayan Penuh/ } \\
\text { Full Fishers } \\
\text { (orang/ people) }\end{array}$ & $\begin{array}{c}\text { Nelayan Sambilan Utama/ } \\
\text { Main part-time Fishers } \\
\text { (orang/people) }\end{array}$ & $\begin{array}{c}\text { Nelayan Sambilan } \\
\text { Tambahan/ } \\
\text { Additional Part-Time } \\
\text { Fisher (orang/people) }\end{array}$ & $\begin{array}{c}\text { Jumlah/ } \\
\text { Total (orang/ } \\
\text { people) }\end{array}$ \\
\hline Komodo & 6,962 & 290 & $1 .=, 720$ & 8,972 \\
Boleng & 756 & 315 & 34 & 1,105 \\
Lembor Selatan & 431 & - & 50 & 481 \\
Macang Pancar & 395 & 170 & 15 & 580 \\
\hline Jumlah/Total & $\mathbf{8 , 5 4 4}$ & $\mathbf{7 7 5}$ & $\mathbf{1 , 8 1 9}$ & $\mathbf{1 1 , 1 3 8}$ \\
\hline
\end{tabular}

Sumber: Statistik Perikanan Tangkap, 2015/Source: Capture Fisheries Statistic, 2015

f. Pariwisata. Sektor pariwisata di Provinsi NTT didominasi oleh wisata alam terutama wisata bahari mulai dari kawasan kepulauan, pantai serta keanekaragaman dan keunikan ekologi laut yang ada di dalamnya, selain itu juga kekayaan alam daratan serta panorama alam yang indah. Adapun kawasan wisata bahari yang ada di wilayah TN Komodo adalah Kawasan TNK di Komodo terletak di Kecamatan Komodo Kabupaten Manggarai Barat. Di lokasi ini banyak ditemukan ikan pelagis besar dan demersal, dan di daratnya lebih mempesona karena dapat bertemu dengan komodo yang merupakan ikon NTT. Selain itu, menurut Kurniawati (2016) aktivitas lainnya selain komodo sebagai obyek utama juga sangat berperan penting dalam memberikan pengalaman bagi wisatawan. Secara keseluruhan peran obyek wisata tersebut telah mampu membantu wilayah Kabupaten Manggarai Barat di dalam meningkatkan perekonomian daerah (Hironimus, Rijanta dan Iskandar, 2019). Penelitian Moi (2017) menunjukkan bahwa meningkatnya wisatawan yang masuk ke dalam destinasi wisata di Labuan Bajo, diikuti dengan meningkatnya lama tinggal wisatawan yang kemudian berujung dengan memberikan dampak pada kenaikan PAD dan pendapatan masyarakat dari sektor pariwisata. g. Pelabuhan. Sumber daya buatan yang terdapat di Kawasan Strategis Nasional TN Komodo berupa infrastruktur perhubungan laut yang terdiri dari pelabungan laut yang terdiri dari Pelabuhan Umum dan Pelabuhan Perikanan. Persebaran pelabuhan di Kabupaten Manggarai Barat sebagaimana disajikan pada Tabel 4.

h. Alur Pelayaran. Alur pelayaran yang berada didalam kawasan TN Komodo terdiri dari alur pelayaran angkutan komersil (Pelni), angkutan laut perintis, dan alur komersil ASDP. Alur pelayaran tesebut merupakan alur penyeberangan antar provinsi. Hasil analisis overlay alur pelayaran pada KSN kawasan TN Komodo disajikan pada peta alur pelayaran sebagaimana Gambar 8.

\section{Penentuan Nilai Penting dan Strategis Nasional}

Kegiatan bernilai penting dan strategis nasional/Obyek Vital Nasional adalah kawasan/ lokasi, bangunan/instalasi dan/atau usaha yang menyangkut hajat hidup orang banyak, kepentingan negara dan/atau sumber pendapatan negara yang bersifat strategis. Hasil penilaian Obyek strategis nasional/proyek strategis nasional/kegiatan strategis di KSN Kawasan Taman Nasional Komodo, sebagaimana disajikan pada Tabel 5.

Tabel 4. Persebaran Pelabuhan di Kabupaten Manggarai Barat, 2017. Table 4. Port Distribution in West Manggarai Regency, 2017.

\begin{tabular}{cllc}
\hline No & $\begin{array}{c}\text { Nama Lokasi Pelabuhan/ } \\
\text { Name Location of Port }\end{array}$ & \multicolumn{1}{c}{$\begin{array}{c}\text { Jenis Pelabuhan/ } \\
\text { Type of Port }\end{array}$} & $\begin{array}{c}\text { Hirarki Klasifikasi/ } \\
\text { Hierarchy Classification }\end{array}$ \\
\hline 1 & Labuan Bajo & Pelabuhan Umum/Public Port & $\mathrm{PP}$ \\
2 & Komodo & Pelabuhan Umum/Public Port & $\mathrm{PR}$ \\
3 & Nangalili & Pelabuhan Umum/Public Port & $\mathrm{PL}$ \\
4 & Rinca & Pelabuhan Umum/Public Port & $\mathrm{PL}$ \\
5 & Bari & Pelabuhan Umum/Public Port & $\mathrm{PL}$ \\
6 & PP. Labuan Bajo & Pelabuhan Perikanan/Fishing Port & $\mathrm{PPI}$ \\
\hline
\end{tabular}

Sumber: RIPN, Kementerian Perhubungan (2017), data diolah/ Source: RIPN, Ministry of Transportation (2017), data processed 


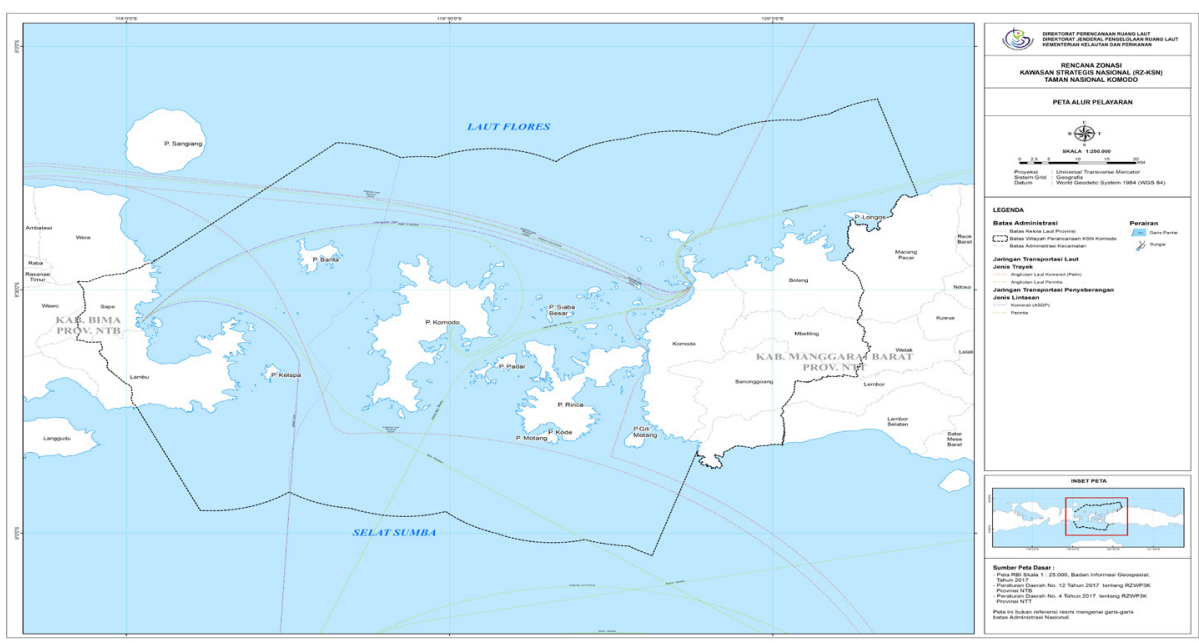

Gambar 8. Alur Pelayaran di Wilayah Perencanaan RZ KSN Komodo. Figure 8. Shipping Lanes in Planning Area of RZ KSN Komodo.

Sumber: KKP (2018a)/Source: KKP (2018a)

Tabel 5. Skoring Nilai Penting dan Strategis Nasional pada KSN Kawasan Taman Nasional Komodo. Table 5. Scoring of Important National Strategic Values in the KSN Komodo National Park Area.

\begin{tabular}{|c|c|c|c|c|c|c|c|c|c|c|c|}
\hline \multirow[b]{2}{*}{ Potensi/Potency } & \multicolumn{9}{|c|}{ Kriteria/Criteria } & \multirow[b]{2}{*}{$\begin{array}{l}\text { Total } \\
\text { Nilai/ } \\
\text { Total } \\
\text { Value }\end{array}$} & \multirow{2}{*}{$\begin{array}{c}\text { Bobot Nilai } \\
\text { Strategis } \\
\text { Nasional/ } \\
\text { Score of } \\
\text { National } \\
\text { Strategic } \\
\text { Value }\end{array}$} \\
\hline & a & $\mathrm{mp}$ & $a k / l$ & npa & e & Se & $\tan /$ & trib & on & & \\
\hline $\begin{array}{l}\text { Pelabuhan Labuan Bajo/ } \\
\text { Port of Labuan Bajo }\end{array}$ & 1 & 1 & 1 & 1 & 1 & 1 & 1 & 1 & 1 & 9 & $\begin{array}{l}\text { Sangat Penting/ } \\
\text { very important }\end{array}$ \\
\hline $\begin{array}{l}\text { Perikanan Tangkap/ } \\
\text { Capture Fisheries }\end{array}$ & 1 & 1 & 1 & 1 & 1 & 1 & 1 & & & 7 & $\begin{array}{l}\text { Sangat Penting/ } \\
\text { very important }\end{array}$ \\
\hline $\begin{array}{l}\text { Perikanan Budidaya/ } \\
\text { Mariculture }\end{array}$ & 1 & 1 & 1 & 1 & 1 & 1 & 1 & & & 7 & $\begin{array}{l}\text { Sangat penting/ } \\
\text { very important }\end{array}$ \\
\hline $\begin{array}{l}\text { Taman Nasional Komodo/ } \\
\text { Komodo National Park }\end{array}$ & 1 & 1 & 1 & 1 & 1 & 1 & 1 & 1 & 1 & 9 & $\begin{array}{l}\text { Sangat Penting/ } \\
\text { very important }\end{array}$ \\
\hline $\begin{array}{l}\text { Kawasan Konservasi Perairan/ } \\
\text { Marine Conservation Area }\end{array}$ & 1 & 1 & 1 & 1 & 1 & 1 & 1 & 1 & 1 & 9 & $\begin{array}{l}\text { Sangat Penting/ } \\
\text { very important }\end{array}$ \\
\hline $\begin{array}{l}\text { Energi Arus Laut/ } \\
\text { Sea Currents Energy }\end{array}$ & 1 & 1 & 1 & 1 & 1 & 1 & 1 & & & 7 & $\begin{array}{l}\text { Sangat penting/ } \\
\text { very important }\end{array}$ \\
\hline $\begin{array}{l}\text { Alur Pelayaran/ } \\
\text { Sea Lanes }\end{array}$ & 1 & 1 & 1 & 1 & 1 & 1 & 1 & 1 & & 8 & $\begin{array}{l}\text { Sangat penting/ } \\
\text { very important }\end{array}$ \\
\hline $\begin{array}{l}\text { Labuh Jangkar/ } \\
\text { Anchorage }\end{array}$ & 1 & 1 & 1 & 1 & 1 & 1 & 1 & 1 & & 8 & $\begin{array}{l}\text { Sangat penting/ } \\
\text { very important }\end{array}$ \\
\hline $\begin{array}{l}\text { Pariwisata Prioritas/ } \\
\text { Tourism Priority }\end{array}$ & 1 & 1 & 1 & 1 & 1 & 1 & 1 & 1 & 1 & 9 & $\begin{array}{l}\text { Sangat Penting/ } \\
\text { very important }\end{array}$ \\
\hline $\begin{array}{l}\text { Palapa Ring (Kabel Bawah Laut)/ } \\
\text { Palapa Ring (Submarine Cable) }\end{array}$ & 1 & 1 & 1 & 1 & 1 & 1 & 1 & 1 & & 8 & $\begin{array}{l}\text { Sangat penting/ } \\
\text { very important }\end{array}$ \\
\hline
\end{tabular}

\section{Keterangan/Remaks}

DAMPAKIIMPACT

a) Kedaulatan, pertahanan dan kemanan negaral National sovereignty, defense and security

b) Pertumbuhan ekonomi/economic growth

c) Sosial Budaya/Social Culture

d) Pendayagunaan SDA dan Teknologi Tinggi/ Utilization of natural resources and high technology

e) Fungsi dan daya dukung lingkungan hidup/

Functions and carrying capacity of the environment (ada/exist $=1$; tidak ada/not exist $=0$ )
SEBARAN/Distribution

a) Lokal/local

b) Regional/regional

c) Nasional/national

d) Internasional/international

(ada/exist=1; tidak ada/not

exist $=0$ )
Kelas Bobot Strategis Nasional/

Class Score of National Strategic:

Total Nilai dibuat tiga selang kelas

Total Value Ranked Three Classes:

- Kurang penting/Less important $(1-3)$;

- Penting/important (4 - 6);

- Sangat Penting/very important (7 - 9). 
Upaya penting dalam penyusunan RZ KSN adalah mengalokasikan ruang laut yang mempunyai bobot sangat penting pada wilayah perencanaan melalui dua mekanisme pokok, yaitu: (a) Mekanisme teknis, dan; (b) Mekanisme sosial. Mekanisme teknis dilakukan dengan pertimbangan-pertimbangan teknis-ekologis sebagai hasil dari identifikasi dan kajian potensi dan kondisi sumber daya alam dan lingkungan pesisir dan pulau-pulau kecil di kawasan strategis nasional (KSN). Sementara itu mekanisme sosial dilakukan dengan pertimbanganpertimbangan sosial dan ekonomi sebagai hasil dari identifikasi dan kajian potensi sosial-ekonomi dan kelembagaan, serta mempertimbangkan hasil kesepakatan. Dengan demikian mekanisme teknis dan sosial harus digunakan secara bersama-sama kerena pentingnya implementasi rencana zonasi tersebut bagi keberlanjutan pengelolaan kawasan strategis nasional (KSN).

Mekanisme sosial perlu dilakukan atas dasar fakta bahwa masyarakat yang selama ini memanfaatkan sumber daya alam pesisir dan pulau-pulau kecil (perikanan misalnya) tidak sedikit yang berdasarkan pada adanya hak ulayat laut. Dalam hak ulayat tersebut umumnya tergambar jelas batas-batas kewenangan suatu kelompok masyarakat dalam memanfaatkan sumber daya perikanan dimaksud. Adanya hak-hak ulayat tersebut tidak bisa diabaikan demi alasan teknis, karena justru hal ini dapat berpotensi menjadi sumber konflik dalam pengelolaan sumber daya alam pesisir dan pulau-pulau kecil. Adanya konflik ini menjadikan penetapan zonasi tidak bisa berjalan secara efektif.

Oleh karena itu pengalokasian ruang laut bernilai sangat penting pada KSN harus memperhatikan kepentingan dan keterlibatan masyarakat dalam proses penetapannya. Mujio, Adrianto, Soewardi \& Wardiatno (2016) menyatakan bahwa semakin banyak stakeholder dan semakin beragam latar belakang pendidikan dan profesinya akan mempertajam dalam analisis pemetaan konflik. Dengan adanya partisipasi masyarakat tentunya akan semakin mendekatkan upaya menemukan titik temu antara kepentingan teknis-ekologis yang dilakukan suprastruktur dengan kepentingan sosial yang dilakukan masyarakat.

Berdasarkan hasil skoring terhadap kegiatan yang bernilai penting dan strategis nasional, apabila masih terdapat konflik pemanfaatan ruang, misalnya berupa kepentingan kewenangan, maka dilakukan dengan cara pengambilan keputusan bersama antar pemangku kepentingan. Berdasarkan hasil analisis kesesuaian dan dengan memperhatikan keberadaan Objek Vital Nasional/ keberadaan Proyek Strategis Nasional yang ada di Kawasan Strategis Nasional (KSN) Kawasan TN Komodo, Rencana Pola Ruang Laut untuk Kegiatan Bernilai Penting dan Strategis Nasional, terdiri atas: (1) Kawasan Pemanfaatan Umum seluas $24.167,24 \mathrm{Ha}(2,5 \%)$, terdiri dari Zona Pariwisata, Zona Pelabuhan, Zona Pelabuhan Perikanan, dan Zona Pengelolaan Energi; (2) Kawasan Konservasi seluas $24.167,24 \mathrm{Ha}$ (25,1\%) yang berupa Kawasan Konservasi Perairan, Pesisir dan Pulau-pulau Kecil dan Taman Nasional Komodo yang merupakan inti dari KSN Taman Nasional Komodo, dan; (3) Alur Laut. Sedangkan Rencana Pola Ruang Laut untuk Arahan Alokasi Ruang RZWP-3K berupa perairan seluas 466.911,08 $\mathrm{Ha}(48 \%)$ diatur lebih lanjut dalam RZWP-3-K Provinsi NTT dan RZWP-3-K Provinsi NTB yang diarahkan untuk alokasi kegiatan utama pariwisata, perikanan dan hutan mangrove.

Rencana alokasi ruang RZ KSN di perairan ditetapkan sebagai hasil analisis tiga dimensi ruang, yaitu permukaan, kolom, dan dasar laut. Alokasi Ruang Rencana Zonasi Kawasan Strategis Nasional, terdiri dari: 1) Struktur Ruang Laut yang merupakan susunan pusat pertumbuhan kelautan dan sistem jaringan prasarana dan sarana laut yang berfungsi sebagai pendukung kegiatan sosial ekonomi masyarakat yang secara hierarkis memiliki hubungan fungsional, dan 2) Pola Ruang Laut adalah distribusi peruntukan ruang dalam wilayah perairan dan wilayah yurisdiksi yang peruntukan ruangnya untuk kawasan pemanfaatan umum, kawasan konservasi, alur laut, dan/atau kawasan strategis nasional tertentu.

\section{Rencana Struktur Ruang Laut.}

Berupa sistem jaringan sarana dan prasarana kelautan dan perikanan dan sistem jaringan transportasi laut. Hal ini sejalan dengan arahan perencanaan ruang laut yang tertuang di dalam Peraturan Pemerintah Nomor 32 Tahun 2019 tentang Rencana Tata Ruang Laut.

Sistem jaringan prasarana dan sarana laut didalam Kawasan Strategis Nasional (KSN) Kawasan TN Komodo berupa: (a). Alur pelayaran yang terdiri alur pelayaran nasional, alur pelayaran 
regional, alur pelayaran lokal, dan alur pelayaran khusus; (b). Alur pipa bawah laut yang terletak di Perairan Sekitar Sape yang berfungsi untuk menunjang kegiatan PLTMG Bima 2; dan (c). Kabel bawah laut yang terdiri dari kabel telekomunikasi dan kabel serat optik.

Sistem jaringan transportasi laut berupa tatanan kepelabuhanan nasional. Tatanan kepelabuhanan nasional dilaksanakan sesuai dengan ketentuan peraturan perundangundangan. Tatanan kepelabuhanan yang ada didalam perencanaan KSN Kawasan TN Komodo terdiri atas: (a) Pelabuhan Pengumpul Labuan Bajo; (b) Pelabuhan Pengumpan Regional Sape; (c) Pelabuhan Perikanan (Pangkalan Pendaratan Ikan Labuan Bajo), dan; (d) Pelabuhan Penyeberangan Sape. Hasil analisis disajikan dalam Peta rencana struktur ruang laut RZ KSN Kawasan TN Komodo sebagaimana pada Gambar 9.

\section{Rencana Pola Ruang Laut.}

Berupa Kawasan Pemanfaatan Umum, Kawasan Konservasi, Kawasan Strategis Nasional Tertentu dan Alur Laut dijabarkan ke dalam zona dan arahan pemanfaatan untuk setiap zona pada masing-masing kawasan yang dikhususkan terhadap ruang laut yang memiliki nilai penting dan strategis untuk kepentingan nasional. Rencana pola ruang laut pada RZ KSN terdiri dari: Pola Ruang Laut untuk untuk kegiatan bernilai penting dan strategis nasional, dan arahan alokasi ruang untuk RZWP3K. Hasil analisis pola ruang laut yang telah diuraikan di atas disajikan dalam Peta Rencana Pola Ruang Laut RZ KSN Kawasan TN Komodo sebagaimana pada Gambar 10.

Nilai Penting dan Strategis Nasional yang telah dituangkan dalam Rencana Zonasi Kawasan Strategis Nasional (RZ KSN) Taman Nasional Komodo menjadi data dukung utama dalam penyusunan Peraturan Presiden tentang Rencana Zonasi Kawasan Strategis Nasional Taman Nasional Komodo secara komprehensif, holistik, dan terpadu. Komprehensif dengan memperhatikan aspek fisik, lingkungan, sosial, ekonomi, dan budaya. Holistik dengan memperhatikan satu kesatuan wilayah perencanaan pesisir dan pulau-pulau kecil secara menyeluruh dengan menekankan saling keterkaitan antar komponen yang ada di dalamnya. Terpadu dengan memperhatikan keterpaduan wilayah, sektor dan ekosistem.

Nilai penting dan Strategis Nasional yang telah dituangkan dalam Rencana Zonasi Kawasan Strategis Nasional (RZ KSN) Taman Nasional Komodo tersebut diharapkan dapat mengoptimalkan potensi pengembangan perairan, dan memberikan kepastian hukum serta meminimalkan permasalahan/konflik pemanfa atan kawasan perairan di KSN Kawasan Taman Nasional Komodo dan sekitarnya.

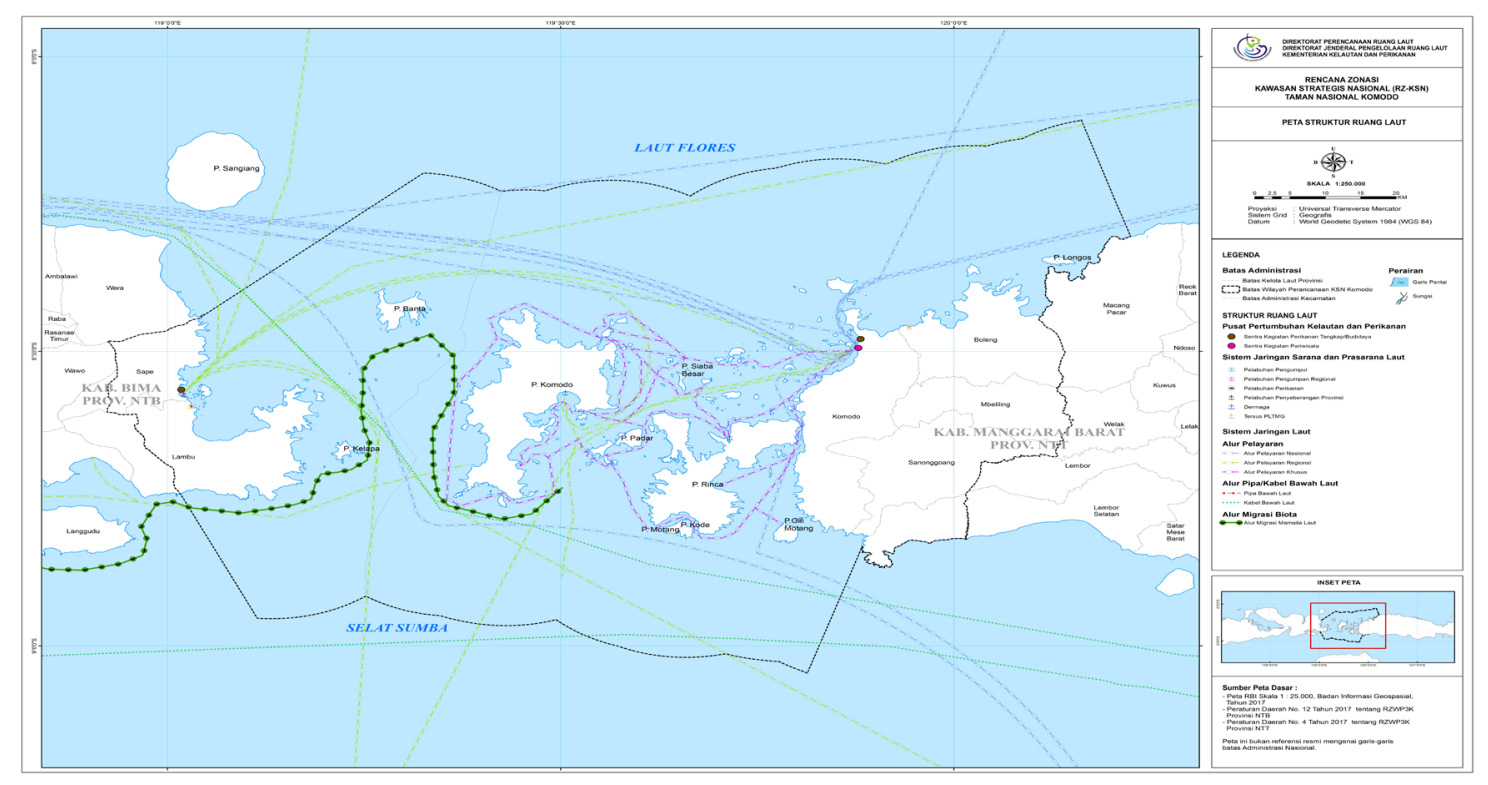

Gambar 9. Peta Rencana Struktur Ruang Laut RZ KSN Kawasan TN Komodo. Figure 9. Map of Marine Spatial Structure Plan of RZ KSN Komodo National Park. 


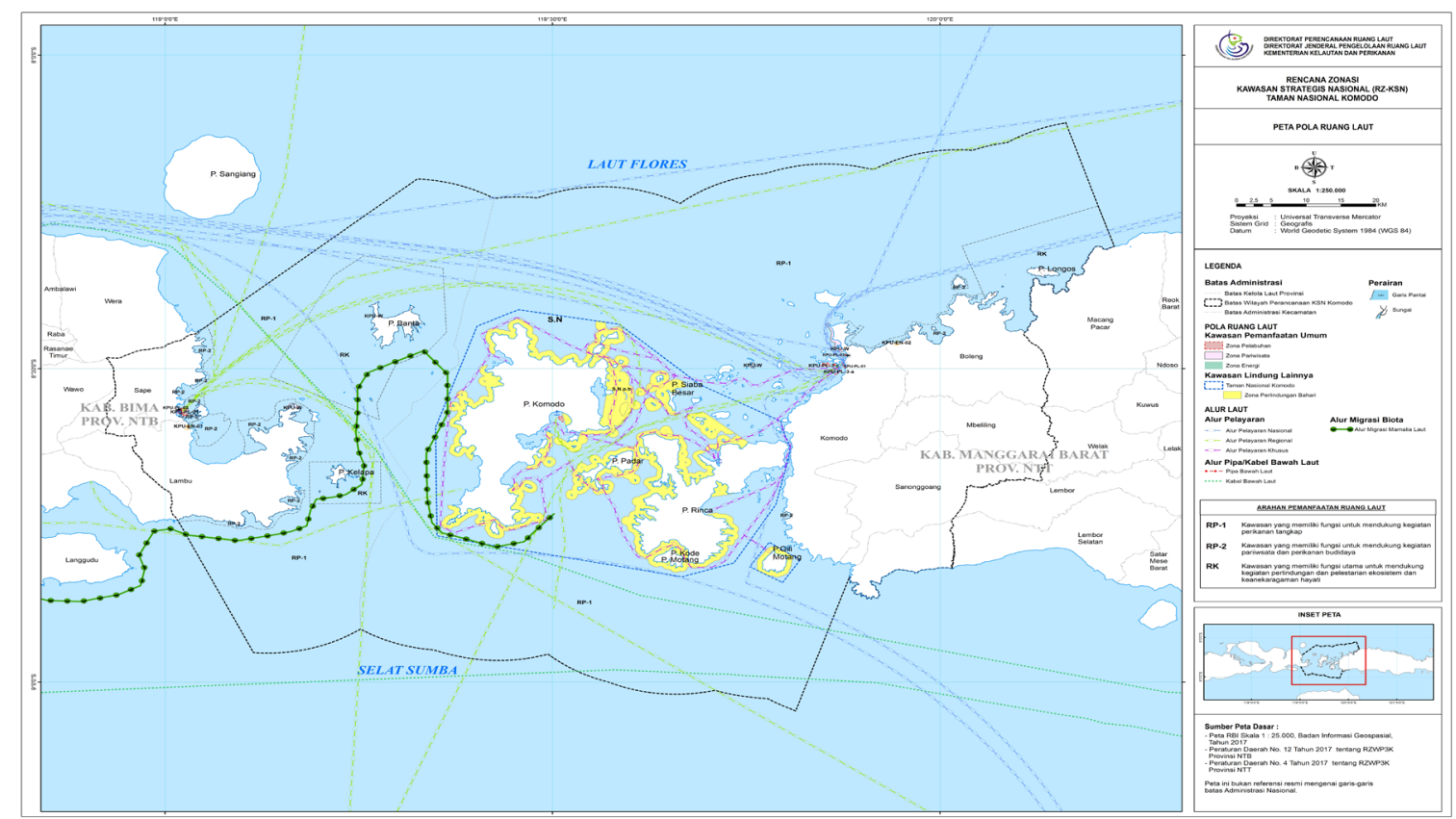

Gambar 10. Peta Rencana Pola Ruang Laut RZ KSN Kawasan TN Komodo. Figure 10. Map of Marine Spatial Pattern Plan of RZ KSN Komodo National Park.

\section{Formulasi Tujuan, Kebijakan dan Strategi}

Alokasi ruang yang terdiri dari struktur dan pola ruang laut disusun dengan pertimbangan Nilai Penting dan Strategis Nasional serta isu-isu pengelolaan yang telah dikemukakan telah disepakati oleh para pemangku kepentingan melalui berbagai forum diskusi kelompok terfokus maupun konsultasi publik. Forum tersebut telah merumuskan tujuan pengelolaan RZ KSN Kawasan TN Komodo sebagai berikut: Mewujudkan Kawasan Taman Nasional Komodo yang berkualitas dan dinamis dalam rangka menjamin kelestarian lingkungan dan kesejahteraan masyarakat berbasis pariwisata berskala dunia yang memiliki keterpaduan dalam pengelolaan Sumber Daya Kelautan yang optimal dan berkelanjutan. Secara ekologis bertujuan untuk melindungi, melestarikan dan memanfaatkan (konservasi) sumberdaya di lingkungan Taman Nasional dan lingkungan pesisir dan pulau-pulau kecil agar terjamin keberadaan dan keberlanjutannya. Secara ekonomis bertujuan untuk: (1) Mewujudkan kawasan destinasi pariwisata berkelas dunia dan mensejahterakan masyarakat; (2) Mengembangkan pusat-pusat pertumbuhan ekonomi yang selaras dengan perwujudan kawasan sebagai destinasi pariwisata, dan; (3) Mendorong inisiatif masyarakat dalam meningkatkan kegiatan ekonomi kreatif. Adapun tujuan sosial budaya dirumuskan sebagai berikut: (1) Meningkatkan kualitas
SDM untuk berperan serta dalam pengelolaan lingkungan dan kegiatan ekonomi kreatif, dan; (2) Mempertahankan kearifan lokal dan nilai-nilai sosial budaya dalam pengelolaan KSN Kawasan TN Komodo. Sedangkan tujuan kelembagaan yaitu: menciptakan keharmonisan dan sinergi serta memperkuat kapasitas kelembagaan antar pemangku kepentingan (pemerintah, masyarakat, dunia usaha).

Kebijakan perencanaan ruang KSN Kawasan TN Komodo dilaksanakan dalam kerangka pengembangan struktur ruang dan pola ruang $R Z$ KSN Kawasan TN Komodo untuk mencapai tujuan penataan ruang KSN Kawasan TN Komodo, yang dijabarkan dalam strategi antara lain:

(1) Mengembangkan dan mengelola kawasan Taman Nasional Komodo secara efektif melalui kemitraan pemerintah, masyarakat, dan dunia usaha serta mengembangkan jejaring kawasan konservasi baik jejaring lokal, regional maupun global;

(2) Mengembangkan teknik dan upaya-upaya rehabilitasi, restorasi dan pemulihan kerusakan sumberdaya di Kawasan TN Komodo melalui partisipasi masyarakat, dunia usaha dan lembaga non-pemerintah;

(3) Meningkatkan pengawasan dan pengendalian pencemaran dan kerusakan sumber daya di kawasan TN Komodo serta 
lingkungan dengan meningkatkan kapasitas aparatur dan melibatkan kelompok-kelompok masyarakat;

(4) Meningkatkan kemudahan akses masyarakat terhadap permodalan usaha, sarana produksi, informasi dan pemasaran

(5) Menciptakan iklim investasi yang kondusif dengan melengkapi perangkat kebijakan dan regulasi, sistem perizinan yang cepat dan transparan, insentif dan dukungan keamanan.

Pelaksanaan Strategi dilaksanakan dalam program-program dan dituangkan dalam rincian indikasi program utama pemanfaatan ruang laut yang menjadi bagian tidak terpisahkan dari Rancangan Peraturan Presiden.

\section{KESIMPULAN DAN REKOMENDASI KEBIJAKAN}

\section{Kesimpulan}

Kondisi dan potensi sumberdaya alam kawasan strategis nasional kawasan Taman Nasional Komodo yang meliputi Keadaan Oseanografi, Potensi Ekosistem Pesisir, Potensi Daerah Penangkapan Ikan, Potensi Daerah Tujuan Wisata Selam, Kawasan Konservasi dan Biota Dilindungi, Daerah Rawan Tsunami, dan Kegiatan Pemanfaatan Perairan Pesisir memiliki nilai penting dan strategis dalam tata kelola kawasan strategis nasional yang dapat dirumuskan dalam perencanaan ruang laut dalam menjawab keberlanjutan fungsi konservasi dan keanekaragaman hayati Kawasan Taman Nasional Komodo

Pengambilan keputusan bersama antar pemangku kepentingan terhadap hasil analisis kesesuaian dan analisis skoring terhadap kegiatan yang bernilai penting dan strategis nasional yang memiliki bobot sangat penting (7-9) dapat digunakan untuk mencegah konflik pemanfaatan ruang dalam menetapkan rencana alokasi ruang laut dengan tetap memperhatikan kepentingan strategis nasional. Rencana alokasi ruang laut di Kawasan Strategis Nasional (KSN) Kawasan TN Komodo, terdiri atas: (1). Kawasan Pemanfaatan Umum, terdiri dari Zona Pariwisata, Zona Pelabuhan, Zona Pelabuhan Perikanan, dan Zona Pengelolaan Energi; (2). Kawasan Konservasi yang berupa Kawasan Konservasi Perairan, Pesisir dan Pulau-pulau Kecil dan Taman Nasional Komodo yang merupakan inti dari KSN Taman Nasional Komodo, dan; (3)
Alur Laut.

Analisis Nilai Penting dan Strategis Nasional yang telah dilakukan menghasilkan Perencanaan Ruang Laut yang bertujuan untuk mewujudkan kawasan yang dikembangkan untuk perlindungan dan pelestarian Taman Nasional Komodo dan konservasi perairan; dan kawasan yang berdaya saing berbasis pengelolaan sumber daya kelautan dan pariwisata dengan prinsip berkelanjutan untuk kesejahteraan masyarakat.

\section{Rekomendasi Kebijakan}

Proses penentuan dan pengambilan keputusan yang melibatkan para pihak dalam menetapkan alokasi ruang laut untuk kegiatan bernilai penting dan strategis nasional dapat direkomendasikan sebagai pembelajaran, sehingga tidak menyisakan persoalan atau konflik sosial maupun tumpang tindih kewenangan dalam pemanfaatan ruang laut. Pembangunan di kawasan TN Komodo dapat mengacu pada rencana tata ruang dan rencana zonasi KSN, sehingga perencanaan pembangunan dapat ditata secara seimbang, tidak melampaui daya dukung dan daya tampung, serta kegiatan konservasi dan ekonomi berjalan sinergis.

Hasil kajian nilai penting dan strategis nasional, berupa Dokumen RZ KSN Kawasan Taman Nasional Komodo direkomendasikan menjadi bahan utama dalam penyusunan Rancangan peraturan presiden, serta mendorong komitmen pemangku kepentingan untuk bersama-sama menyusun indikasi program pembangunan selama 20 (dua puluh) tahun di kawasan strategis nasional tersebut. Mengingat kondisi, potensi dan issue yang berkembang di kawasan taman nasional komodo merupakan satu kesatuan ekosistem yang tidak dapat dipisahkan antara daratan dan perairan, maka pengaturan dalam peraturan presiden dapat dilaksanakan dalam satu ketetapan berupa Peraturan Presiden tentang Rencana Tata Ruang dan Rencana Zonasi Kawasan Strategis Nasional Taman Nasional Komodo.

\section{UCAPAN TERIMA KASIH}

Ucapan terima kasih penghargaan yang setinggi-tingginya penulis sampaikan kepada Direktorat Perencanaan Ruang Laut, khususnya tim penyusun yang telah berkontribusi dalam penyusunan Rencana Zonasi Kawasan Strategis 
Nasional Kawasan Taman Nasional Komodo dan penulisan karya ilmiah ini.

\section{PERNYATAAN KONTRIBUSI PENULIS}

Penulis menyatakan bahwa Surajimerupakan kontributor utama dan Syofyan Hasan, Suharyanto, Yonvitner, Sonny Koeshendrajana, Didit Eko Prasetiyo, Arief Widianto, dan Agus Dermawan merupakan kontributor anggota dalam penulisan karya ilmiah ini sebagaimana terlampir dalam surat pernyataan kontribusi penulis.

\section{DAFTAR PUSTAKA}

Astuti, R. Y., Budisusanto, Y., Pratomo, D.G. \& Sidqi, M. (2018). Analisa Kesesuaian RZWP-3-K dengan Eksisting Penggunaan Ruang Laut Berdasarkan UU. No. 1 Tahun 2014 dan Permen-KP No. 23 Tahun 2016. JURNAL TEKNIK ITS Vol. 7, No. 1 (2018), 2337-3520 (2301-928X Print). Halaman: G 117 - G 120.

Bessie, D. \& Dewi, I. A. L. (2016). Pembaharuan Penilaian Performa Pengelolaan Perikanan menggunakan Indikator EAFM: Kabupaten Kabupaten Sikka, Manggarai Barat, Kabupaten Flores Timur, dan Kabupaten Alor. Universitas Kristen Artha Wacana Kupang, Politeknik Pertanian Negeri Kupang dan WWF Indonesia.

Dinas Kelautan dan Perikanan Provinsi Nusa Tenggara Timur. (2015). Statistik Perikanan Tangkap Provinsi Nusa Tenggara Timur. Kupang.

Hironimus, Y. S., Rijanta, R. \& Iskandar, D. A. (2019). Faktor-faktor yang Mempengaruhi Peran Aktivitas Pariwisata di Taman Nasional Komodo terhadap Pertumbuhan Ekonomi Wilayah Kabupaten Manggarai Barat. Region. Jurnal Pembangunan Wilayah dan Perencanaan Partisipatif Volume 14 Nomor 2. Januari 2019. Halaman: 141-153.

[Kementerian ESDM] Kementerian Energi dan Sumber Daya Mineral. Keputusan Menteri ESDM No. $1567 \mathrm{~K} / 21 / \mathrm{MEM} / 2018$ tentang Rencana Usaha Penyediaan Tenaga Listrik (RUPTL) 2018 2027. (2018). Jakarta.

Kementerian Kehutanan. Keputusan Direktorat Jenderal Perlindungan Hutan dan Konservasi Alam Nomor SK.21 /IV-SET/2012 tentang Zonasi Taman Nasional Komodo. (2012). Jakarta

[KKP] Kementerian Kelautan dan Perikanan. (2018a). Dokumen Final Rencana Zonasi Kawasan Strategis Nasional Kawasan Taman Nasional Komodo. Jakarta: Direktorat Perencanaan Ruang Laut. Jakarta.

[KKP] Kementerian Kelautan dan Perikanan. (2018b). Pedoman Umum Penyusunan Rancana Zonasi Kawasan Laut (draft). Jakarta: Direktorat Perencanaan Ruang Laut.
[KKP] Kementerian Kelautan dan Perikanan. Keputusan Menteri Kelautan dan Perikanan Republik Indonesia Nomor 6/KEPMEN-KP/2018 Tentang Rencana Induk Pelabuhan Perikanan Nasional. (2018c). Jakarta.

[Kemenpar] Kementerian Pariwisata. (2018a). Pengembangan Destinasi Pariwisata Labuan Bajo. Jakarta

[Kemenpar] Kementerian Pariwisata. (2018b). Pengembangan Wisata Kapal Wisata (Yacht) Asing. Jakarta

[Kemenhub] Kementerian Perhubungan. Keputusan Menteri Perhubungan Nomor KP 432 Tahun 2017 tentang Rencana Induk Pelabuhan Nasional. (2017). Jakarta.

Kurniawati, R. (2016). Persepsi Wisatawan Terhadap Atraksi Wisata Animal Watching di Taman Nasional Komodo. Jurnal Destinasi Kepariwisataan Indonesia Vol. 1 No. 1 Juni 2016. Halaman: $67-82$

Moi, S.A. (2017). Implementasi Kebijakan Pemerintah Indonesia dalam Rangka Asean Tourism Strategic Plan 2011-2015 Terhadap Pengelolaan Pariwisata di Labuan Bajo. Jurnal Analisis Hubungan Internasional, Vol. 6 No. 2, Agustus 2017. Halaman: 123-132.

Mujio, Adrianto, L., Soewardi, K. \& Wardiatno, Y. (2016). Analisis Potensi Konflik Pemanfaatan Ruang Kawasan Pesisir: Integrasi Rencana Tata Ruang Darat dan Perairan Pesisir. Sodality: Jurnal Sosiologi Pedesaan, Agustus 2016. Halaman: 139-144.

Pemerintah Daerah Kabupaten Manggarai Barat. Peraturan Bupati Nomor 43 Tahun 2018 tentang Ketentuan Pemanfaatan Ruang dan ljin Prinsip Pemanfaatan Ruang Labuan Bajo. (2018). Manggarai Barat

Peraturan Daerah Nomor 12 Tahun 2017 tentang Rencana Zonasi Wilayah Pesisir dan Pulau-Pulau Kecil Provinsi Nusa Tenggara Barat Tahun 2017-2037. (2017). Mataram.

Peraturan Daerah Nomor 4 Tahun 2017 tentang Rencana Zonasi Wilayah Pesisir dan Pulau-Pulau Kecil Provinsi Nusa Tenggara Timur Tahun 2017-2037. (2017) Kupang.

Peraturan Pemerintah No 13 tahun 2017 tentang Rencana Tata Ruang Wilayah Nasional. (2017). Jakarta.

Peraturan Pemerintah Nomor 50 Tahun 2011 tentang Rencana Induk Pembangunan Kepariwisataan Nasional Tahun 2010-2025. (2011). Jakarta.

Peraturan Pemerintah Republik Indonesia Nomor 32 Tahun 2019 tentang Rencana Tata Ruang Laut. (2019). Jakarta. 
Peraturan Presiden republik Indonesia Nomor 32 Tahun 2018 tentang Badan Otorita Pengelola Kawasan Pariwisata Labuan Bajo Flores. (2018). Jakarta. Produksi Rumput Laut Menurut Kabupaten/Kota di Provinsi Nusa Tenggara Timur, 2011-2016.

Sartin, J., Amkieltiela, \& Khaifin. (2017). Pemantauan Kesehatan Karang Taman Nasional Komodo Tahun 2017. Laporan. WWF Indonesia. Kupang

Subekti, S., \& Winahyu, S.H. (2015). Strategi Pengembangan Bandar Udara Komodo Labuan Bajo. Warta Penelitian Perhubungan, Volume 27, Nomor 4, Juli-Agustus 2015. Halaman: 289-298.

Sunyowati, D. (2008). Penataan Ruang Laut Berdasarkan Intergarated Coastal Management. MIMBAR HUKUM Volume 20 Nomor 3. Oktober 2008. Halaman: 411-588.

The Nature Conservancy Indonesia Coastal \& Marine Program. (2001). Komodo National Park Cetacean Surveys: a Rapid Ecological Assessment of Cetacean Diversity, Abundance and Distribution. Interim Report-October 2001. The Nature Conservancy Indonesia Coastal \& Marine Program. Jakarta: Kahn, B.

Undang-Undang Republik Indonesia Nomor 32 Tahun 2014 Tentang Kelautan. (2014). Jakarta. Yonvitner, Boer, M., Akmal, S.G., \& Andi, I.S. (2018). Kerentanan Intrinsik dan Risiko Pemanfaatan Perikanan: Analisis Berbasis Data Poor untuk Pengelolaan Berkelanjutan. Jurnal Pengelolaan Perikanan Tropis, Volume 2 Nomor 2, Desember 2018. Halaman: 54-60.

Yuneni, R.R. (2017). Estimasi Daya Dukung Wisata Selam di Lokasi Penyelaman Taman Nasional Komodo Kabupaten Manggarai Barat (Versi 1) dalam upaya berpariwisata laut yang bertanggung jawab. Laporan. WWF Indonesia. Kupang. 